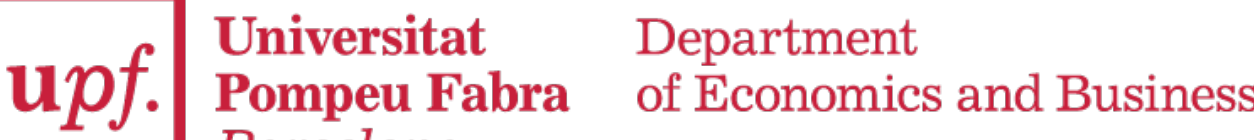 Barcelona
}

Economics Working Paper Series

Working Paper No. 1816

Capital controls, domestic macroprudential policy and the bank lending channel of monetary policy

\author{
Andrea Fabiani, Martha López Piñeros, \\ José-Luis Peydró, and Paul E. Soto
}

August 2021 


\title{
Capital Controls, Domestic Macroprudential Policy and the Bank Lending Channel of Monetary Policy
}

\author{
Andrea Fabiani Martha López Piñeros José-Luis Peydró Paul E. Soto
}

\begin{abstract}
We study how capital controls and domestic macroprudential policy tame credit supply booms, respectively targeting foreign and domestic bank debt. For identification, we exploit the simultaneous introduction of capital controls on foreign exchange (FX) debt inflows and an increase of reserve requirements on domestic bank deposits in Colombia during a strong credit boom, as well as credit registry and bank balance sheet data. Our results suggest that first, an increase in the local monetary policy rate, raising the interest rate spread with the United States, allows more FX-indebted banks to carry trade cheap FX funds with more expensive peso lending, especially toward riskier, opaque firms. Capital controls tax FX debt and break the carry trade. Second, the increase in reserve requirements on domestic deposits directly reduces credit supply, and more so for riskier, opaque firms, rather than enhances the transmission of monetary rates on credit supply. Importantly, different banks finance credit in the boom with either domestic or foreign (FX) financing. Hence, capital controls and domestic macroprudential policy complementarily mitigate the boom and the associated risk-taking through two distinct channels.
\end{abstract}

JEL codes: E52; E58; F34; F38; G21; G28.

Keywords: Capital controls; Macroprudential and monetary policy; Carry trade; Credit supply; Risk-taking.

\footnotetext{
* This draft is from August 2021 (first draft: 2018). Andrea Fabiani: Universitat Pompeu Fabra, Barcelona GSE, andrea.fabiani@upf.edu; Martha López Piñeros: Banco de la República, mlopezpi@banrep.gov.co; José-Luis Peydró: Imperial College London, ICREA-Universitat Pompeu Fabra-CREI-Barcelona GSE, CEPR, jose.peydro@gmail.com; Paul E. Soto: FDIC, psoto@fdic.gov. We thank for helpful comments Philippe Bacchetta, Fernando Broner, Andrea Caggese, Dmitry Kuvshinov, Friederike Niepmann, Björn Richter, Damiano Sandri, Hernando Vargas, Carolina Villegas Sanchez, Jurica Zrnc and, especially, Bent Sorensen and Nadav Ben Zeev (discussants), and seminar and conference participants at CREI, UPF, Barcelona GSE Summer Forum on International Capital Flows, CEPR-ECB International Macroeconomics and Finance Programme Annual Meeting, University of Strathclyde and the Banco de Chile, IADB and JIE Conference on "Financial Frictions: Macroeconomic Implications and Policy Options for Emerging Economies". The views expressed in the paper are solely those of the authors and do not necessarily represent the views of the Banco de la República and of the FDIC or the United States. Paul Soto's research was largely conducted while he was affiliated with UPF. Project supported by a 2018 Leonardo Grant for Researchers and Cultural Creators, BBVA Foundation, by the European Research Council (ERC) under the European Union's Horizon 2020 research and innovation programme (grant agreement No 648398), from the PGC2018-102133-B-I00 (MCIU/AEI/FEDER, UE) grant and the Spanish Ministry of Economy and Competitiveness, through the Severo Ochoa Programme for Centres of Excellence in R\&D (SEV-2015-0563).
} 


\section{Introduction}

Credit booms greatly amplify business cycle fluctuations and are the main predictors of financial crises, especially credit booms that are financed with foreign liquidity (Gourinchas and Obstfeld, 2012; Jordà, Schularick, and Taylor, 2011; Mendoza and Terrones, 2008; Reinhart and Reinhart, 2008; Schularick and Taylor, 2012). Macroprudential policies, including capital controls (CC), try to tame excessive credit booms. Since the Global Financial Crisis (GFC) of 2008-2009, macroprudential policies have become increasingly popular among both academics and policymakers (Freixas, Laeven and Peydró, 2015) and their use has risen constantly (Claessens, 2015; Alam et al., 2019). Moreover, the International Monetary Fund (IMF) has endorsed capital controls as a temporary and last resort tool for managing credit booms led by large capital inflows, especially when room for standard macroeconomic policy is exhausted (Blanchard, 2013; IMF, 2012, 2018; Ostry et al., 2010; Qureshi et al., 2011).

In the same spirit, a class of models rationalizes capital controls as a Pigouvian tax to reduce the negative externalities on systemic risk and aggregate demand associated with excessive foreign debt (Benigno et al., 2016; Bianchi, 2011; Brunnermeier and Sannikov, 2015; Jeanne and Korinek, 2010; Korinek, 2011, 2018; Korinek and Sandri, 2016; Schmitt-Grohé and Uribe, 2016). Other authors support capital controls based on the idea that controls insulate local monetary policy from shocks originated in global financial centers (Rey, 2015; Farhi and Werning, 2012, 2014, and 2016; Davis and Presno, 2017).

We analyze the effects of capital controls and domestic macroprudential policy on credit supply. For identification, we exploit the simultaneous introduction of capital controls on foreign exchange (FX) debt inflows and an increase of reserve requirements on domestic bank deposits in Colombia during a strong credit boom, as well as the cross-sectional implications of these policies on banks depending on their ex ante, sticky capital structure. We also exploit administrative credit registry and supervisory bank balance sheet data. In brief, we find the following robust results.

First, banks use cheaper FX-funding from abroad to arbitrage contractionary local monetary (interest rate) policy. An increase in the local monetary policy rate raises the interest rate differential with respect to the United States, allowing more FX-indebted banks to carry trade 
cheap FX-funds with expensive local credit supply. The carry trade is stronger during periods of relatively larger deviations from the Covered Interest Parity (CIP) and amplifies bank risk-taking in lending, as it directs the supply of credit toward ex-ante riskier and relatively opaque local firms. Capital controls, by taxing FX-debt, reduce the interest rate differential and break the carry trade, enhancing the bank-lending channel of local monetary policy rates and reducing bank risktaking.

Second, the increase in reserve requirements on domestic deposits directly reduces credit supply during the boom, and more so for riskier firms, rather than indirectly enhancing the effects of monetary rates on credit supply. Importantly, banks' reliance on domestic deposits and FX-financing are strongly negatively correlated, suggesting that those banks which restrict credit supply more due to capital controls are less influenced by the domestic reserve requirements, and the other way around. This implies that the two policies affect credit supply independently of each other and that both contribute to slowing down the credit boom.

Our main contribution to the literature is to show that both capital controls and domestic macroprudential policy tame credit supply booms, including credit supply to ex-ante riskier firms, by targeting different but complementary sources of bank debt. Capital controls target bank foreign funding, thereby improving the effectiveness of the bank lending channel of local monetary policy. Domestic macroprudential policy targets bank domestic debt, directly attenuating credit supply booms. As credit booms stem from both foreign and local liquidity, and we find that banks which finance the credit boom with domestic deposits rely less on foreign (FX) debt (and vice versa), our results suggest that a Tinbergen rule with two (macroprudential) instruments is necessary to tackle the two (intermediate) objectives (sources of liquidity). In other terms, the two macroprudential instruments target the two sources of bank debt, foreign and domestic, that drive the credit boom.

The remaining of this Introduction provides a detailed preview of the paper and a discussion of the related literature and its contrast with this paper.

Preview of the paper. We analyze two related research questions. First, we ask whether (and if so, why) capital controls (CC) on FX-financing strengthen the bank-lending channel of monetary policy by increasing the pass-through of variations in the local policy rate to domestic credit, and the implications of this for bank risk-taking. Second, we investigate the impact of 
domestic macroprudential measures on credit supply, in particular reserve requirements (RR) levied on bank local financing through household and firm deposits, as well as whether RR affects the impact of monetary policy rates on credit supply. By doing so, we can analyze whether the two macroprudential measures operate through different channels targeting respectively bank foreign or domestic liabilities, and whether they help mitigate credit supply booms, including the risks stemming from credit expansion during a boom.

Our work is based on two administrative datasets provided by the Colombian Financial Supervisory Authority. First, we have access to the National Credit Registry (CR), which collects detailed quarterly corporate loan information at the loan-level. The CR tracks information on the universe of commercial loans provided to nonfinancial companies. Second, we have access to bank supervisory quarterly balance sheets, which include data on bank size, profitability, capital, nonperforming loans (NPL), and, most importantly for our purposes, the volume of the sources of bank financing taxed through RR and CC (domestic deposits as well as FX funding). We analyze the monetary policy spread rate (as well as the local policy rate) variation on domestic bank credit over the three-year period from 2005Q2 to 2008Q2 (the period ends before the Global Financial Crisis (GFC)), and the connections with following macroprudential policies.

For capital controls, we exploit the Central Bank of Colombia's introduction in May 2007, during a strong credit boom, of a 40 percent unremunerated reserve requirement (URR) on FX debt inflows. At the time, local interest rates - as reflected by the overnight interbank rate - were as high as 8.4 percent. Hence, the new regulation resulted in high taxation of FX debt inflows as a large part (40 percent) of the inflows were in the central bank as unremunerated reserves. CCs were borne by the banks to the extent that FX funding was raised to finance peso investments, ${ }^{1}$ including lending, and were deposited for six months at the central bank without any remuneration; the deposit could be withdrawn before this deadline, but upon the payment of a heavy fee (decreasing in time and ranging from 9.4 percent of the deposit in the first month to 1.6

\footnotetext{
${ }^{1}$ When a bank's FX funding finances FX loans to local firms, the bank's customer pays the CC (in other terms, to avoid double taxation of capital inflows, bank FX funding is exempted). We also analyze FX loans to firms.
} 
percent during the sixth and last month). CCs were lifted by October 2008 amid signs of an economic slowdown related to the unfolding of the GFC after Lehman Brothers' collapse. ${ }^{2}$

Concerning the domestic macroprudential measures, we exploit a contemporaneous policy change to traditional reserve requirements (RR) on peso-denominated deposits. In May 2007, the Central Bank introduced a marginal RR on bank deposits, on top of the ordinary reserve requirement, applied to the overall volume of new deposits received after May $7^{\text {th }}, 2007$. The marginal RR was not remunerated (at a time of high local interest rates) and was initially fixed at 27 percent for checking deposits and 12 percent for savings deposits, though it was eventually uniformed at 27 percent for both savings and checking deposits by June $2007 .^{3}$

Both CC and RR are non-random, but rather induced by the credit boom, which affects both the demand and the supply of credit, i.e. both firms' and banks' financing and lending strategies. In this respect, we identify credit supply channels by exploiting variation in loan conditions for the same firm, in a given year:quarter, across banks with different exposure to either CC or RR. Put differently, we exploit ex-ante heterogeneity in bank foreign (FX) funding and local funding (domestic deposits), respectively, as capital structures tend to be sticky over time. Therefore, we run loan-level regressions saturated with firm*year:quarter fixed effects, controlling for all idiosyncratic, observed and unobserved, time-varying unobserved shocks at the firm level (Khwaja and Mian, 2008). ${ }^{4}$ Moreover, to understand the interaction of CC and RR with the local monetary policy rate, we further interact banks' exposures with local policy rates (Kashyap and Stein, 2000; Jiménez et al., 2012, 2014), and crucially with the spread between the local and the US monetary rates. We also analyze the impact of macroprudential policies on risk-taking in credit supply (Jiménez et al., 2017).

\footnotetext{
${ }^{2}$ Together with CC, the Central Bank fixed a cap on banks' gross FX-position (i.e. the sum of on- and off-balancesheet $\mathrm{FX}$ assets and liabilities), equal to $500 \%$ of banks regulatory capital, which further constrained banks' ability to access FX-financing.

${ }^{3}$ At the time of the introduction of the marginal RR (May 2007), the level of the ordinary RR was $12 \%$ and $6 \%$ for checking and savings deposits, respectively, but it was eventually levelled at $8.3 \%$ in June of 2007 .

${ }^{4}$ Alternatively, in robustness checks, we control for borrower demand via industry*time fixed effects for the sample of all firms, so to include as well those firms indebted with only one bank, which are excluded from the application of firm*time fixed effects.
} 
Our main findings are as follows. ${ }^{5}$ Our results show that using the local-versus-U.S. policy rate differential (spread), before $\mathrm{CC}$, banks with higher (versus lower) ex-ante FX funding increase their credit supply relatively more when the differential monetary rate goes up. ${ }^{6}$ Moreover, after CC, these banks cut credit supply more sharply in reaction to an increase in the monetary interest rate differential. The effects are both statistically and economically significant. Before CC, following a 1 percentage point (p.p.) increase in the monetary policy interest rate spread, banks with a 1 standard deviation (s.d.) higher FX funding increase lending (to the same firm in the same quarter) by 3.8 p.p.. After $\mathrm{CC}$, however, the same variations in the monetary rate spread and FX funding are associated with a relative reduction in credit by 7.3 p.p. (as compared to the ex-ante effect of interacted FX funding and policy rate spread), resulting in an overall statistically significant contraction of credit supply by 3.5 p.p.. These findings are consistent with a carry trade strategy by local banks, which borrow cheaply in FX to lend at higher rates in pesos, and with CC breaking such carry by strongly increasing the cost of bank FX borrowing. ${ }^{7}$

The carry trade affects local companies heterogeneously. We sort firms according to several proxies of pre-policy riskiness: the average interest payments on bank loans, the average share of bank loans with short maturity, i.e. below one year, a dummy variable for whether a firm ever defaulted on a bank loan, and a dummy variable describing whether a company's balance sheet is publicly supervised or not, which we interpret as a proxy for firm's opaqueness. Consistently across the different risk measures, we find that the pre-CC expansion in credit supply due to carry trade favors relatively riskier and opaque firms, whose credit also suffers a sharper reduction after the enforcement of CC.

\footnotetext{
${ }^{5}$ In loan level regressions exploiting time variation only, we find that before the introduction of the macroprudential measures, an increase in the spread between the Colombian and the US monetary policy rates (or in the Colombian policy rate) is not associated to a significant reaction in bank credit. However, after (compared to before) the implementation of the macroprudential policies, higher monetary policy rates imply lower credit volume.

${ }^{6}$ We do not find evidence of a significant interaction of exposure to RR with the local interest rate policy, or the difference between the local and the US monetary rates.

${ }^{7}$ While the main focus of our paper rests on the interaction of $\mathrm{CC}$ with local interest rate policy, we also provide evidence that $\mathrm{CC}$ halt the dependence of domestic bank credit from global shocks. We show that absent $\mathrm{CC}$, a tightening of global liquidity conditions (as proxied by a jump in the VIX), and/or a fall in global demand (captured by a decline in oil prices), triggering a depreciation of the Colombian currency, pushes more FX-indebted banks to cut credit. The introduction of CC reduce those effects, therefore dampening the implications of global shocks for bank credit. These findings align, among others, to the cross-country aggregate evidence in Zeev (2017), who shows that output is less sensitive to global credit supply shocks in countries with CC in place. For cross-country aggregate evidence against this hypothesis, see Bergant et al. (2020).
} 
To further understand the mechanism behind our results we provide two additional tests. First, we rerun the analysis over a representative subsection of credit registry loans for which we can access the breakdown by currency (peso versus FX). We find that the just-described results are driven by corporate lending in peso. This finding is reassuring for two reasons: i) reinvesting globally borrowed FX funds in local peso loans rather than FX loans grants higher returns, given the positive policy risk-free rate differential; ii) banks would bear the $\mathrm{CC}$ tax only if FX funds were reinvested in peso-denominated assets, so that credit supply variations induced by $\mathrm{CC}$ must show up among peso loans. ${ }^{8}$ As a second test, we substitute the Colombia-U.S. policy rate spread with the deviations from the CIP computed by Du and Schregher (2016) over the three-month sovereign yield spread between Colombia and U.S. rates. Indeed, our results go through, i.e. positive variations in deviations from the CIP are associated with a relative jump (descent) in credit supply by higher FX-indebted banks before (after) the introduction of CC. This finding is important, as banks mostly hedge their FX liabilities and CIP deviations grant carry trade returns on top of the costs associated with hedging. ${ }^{9}$

Our estimates suggest that carry trade lending implies higher bank risk-taking. During the boom, it increases the leverage of risky and opaque companies, which are likely to suffer more during a subsequent bust. At the same time, banks finance this risk-taking through FX non-core liabilities, which tend to be more fragile (Dagher and Kazimov, 2015; Demirgüç-Kunt and Huizinga, 2010; Hahm, Shin and Shin, 2013; IMF, 2019; Ivashina, Scharfstein and Stein, 2015). In this respect, $\mathrm{CC}$ reduce banks' risk-taking (on assets and liabilities), on top of enhancing the bank-lending channel by halting one way for arbitraging local monetary rate policy.

After the introduction of RR, banks with higher ex-ante exposure to RR (higher ex-ante reliance on savings deposits and checking deposits) cut credit supply - i.e. reduce lending to the same firm at the same time compared with banks less exposed to RR. Moreover, this reduction in credit supply is robust to controlling for exposure to $\mathrm{CC}$, or to $\mathrm{CC}$ and its interaction with the

\footnotetext{
${ }^{8}$ Note that if banks borrowed in FX to finance FX loans, the CC would be borne by the ultimate borrower, i.e. a local company. The reduction in FX loans associated with CC would show up as a demand shock, which is controlled for in our empirical setting by firm*year:quarter fixed effects (Khwaja and Mian, 2008).

${ }^{9}$ The effect of CIP deviations also survives if we additionally include the interaction of bank FX funding with the component of the three-month sovereign spread which is not accounted for by CIP-deviations, i.e. the three-month forward premium. Note that in our sample period CIP deviations are relatively small as compared to those observed after the Global Financial Crisis, but nonetheless account for roughly 17 percent of the mean sovereign yield spread between Colombia and the United States.
} 
local policy rate, a first suggestion that the two macroprudential channels affect credit supply through two distinct channels. The robust results suggest a large economic impact of RR on bank credit supply. A 1 s.d. overall increase in ex-ante deposits affected by the RR shock (i.e. the sum of checking deposits and saving deposits) implies a 5.4 p.p. reduction in bank credit supply. Moreover, the RR policy change exerts heterogeneous effects across firms, with riskier and more opaque companies significantly more affected.

\section{[Insert Figure 1 here]}

A final question is whether $\mathrm{CC}$ and $\mathrm{RR}$ affect different lenders through distinct channels, and whether both instruments are necessary to tame credit booms and associated risk-taking. The scatterplot in Figure 1, reporting bank reliance on local savings deposits and checking deposits on the $\mathrm{x}$-axis and bank FX funds on the y-axis (both measures are expressed as a share of total assets), indicates that this is the case. Banks more exposed to RR (domestic bank deposits) are less exposed to CC (FX bank funding), and over the period of analysis, the two variables are correlated negatively (by a factor of $37 \%$, significant at a $1 \%$ level). ${ }^{10} \mathrm{Hence}, \mathrm{CC}$ and $\mathrm{RR}-$ i.e. macroprudential measures targeting foreign and domestic bank debt, respectively - affect credit supply through different channels.

Related literature. We contribute to several strands of literature. First, as we show that capital controls, by reducing banks' carry trades, increase the effectiveness of variations of the local monetary policy rate on bank credit supply, we contribute to the large literature on the bank lending channel (e.g. Bernanke and Gertler, 1995; Kashyap and Stein, 2000; Jiménez et al., 2012 and 2014; Acharya et al., 2020), including the related literature on international finance and monetary policy (e.g. Bräuning and Ivashina, 2020a, 2020b; Bruno and Shin, 2015a, 2015b; Cetorelli and Goldberg, 2012; Morais et al., 2019; Rey, 2015).

Several studies investigate empirically the extent of monetary policy autonomy depending on the degree of capital account openness, often in a cross-country framework (e.g. Klein and Shambaugh, 2015; Han and Wei, 2018). We contribute to this literature by showing a specific mechanism through which capital inflows reduce the pass-through of local interest rate policy to

\footnotetext{
${ }^{10}$ The two channels operate independently and are both significant in regressions in which both channels are allowed to affect bank credit.
} 
domestic credit, namely carry trade strategies by domestic banks. ${ }^{11}$ This finding is consistent with recent theoretical insights from Cavallino and Sandri (2019) that a local monetary contraction - by widening the interest rate differential between a small open economy and the rest of the world - drives carry trade inflows, which can significantly increase credit and risk in the local economy. On the empirical front, Fendoglu, Gulsen and Peydró (2019) document, in accordance with our results, that carry trade inflows on the interbank market impaired the bank lending channel of monetary policy in Turkey. Crucially, we show that capital controls are effective in breaking the carry trade, thereby contributing to increase the pass-through (effectiveness) of domestic monetary policy rates to bank credit supply (postulated by Rey, 2015). Furthermore, we find that CC reduce bank risk-taking in both bank assets and liabilities. The pre-CC bank carry trade, driven by the local interest rate policy, increases credit supply to the ex-ante riskier and more opaque firms, and banks finance this risk-taking with FX fragile funding. This result depicts a previously overlooked but nonetheless important prudential mechanism of CC, especially beneficial in light of the poor performance of carries during major financial downturns, including the GFC (Koijen et al., 2018).

Closer to our paper, Dias et al. (2021) exploit the Colombian CC in 2007 to analyze the relation between capital controls and monetary policy. Similarly to us, they conclude that $\mathrm{CC}$ strengthen the transmission of monetary policy rates on lending. However, our focus is different, centered on the influence of local (as opposed to international) monetary policy. In particular, we analyze a particular mechanism, namely banks' carry trade from cheaper FX funds to the supply of credit in higher-rate peso loans (and even more to riskier and opaque local firms), which we show to be especially reactive to the difference between local and international policy rates. Moreover, we analyze the interaction with different macroprudential policies, finding that capital controls and domestic macroprudential policy complementarily mitigate the boom and the associated risk-taking through two distinct channels, independently operating through global and domestic liquidity, respectively.

\footnotetext{
${ }^{11}$ Other studies focus on carry trades by large nonfinancial companies (NFCs) in Emerging Markets (Acharya and Vij, 2016; Caballero, Panizza, and Powell, 2016; Bruno and Shin, 2017), and highlight how their U.S. dollar debt increases when carry trade is more favorable. Liao (2020) shows that carry trade explains a large fraction of international bond issuance. Differently, our attention rests on carry trades by domestic banks in Emerging Markets, involving local currency loans to domestic NFCs, including SMEs.
} 
Our paper additionally speaks to a growing literature on the deviations from CIP. ${ }^{12}$ In particular, consistent with our findings, Avdjiev et al. (2019) document that a stronger USD is associated with significant CIP-deviations and with a reduction in USD-denominated crossborder banking flows. We show that CIP-deviations can hamper the transmission of local policy rate hikes to domestic credit and that $\mathrm{CC}$ are eventually useful to enhance such transmission.

We also contribute to the literature by showing complementarities between domestic macroprudential policies and capital controls, highlighted theoretically by Korinek and Sandri (2018). Credit booms stem from both local and foreign sources of liquidity, with the latter flowing to the local economy either through foreign lending or through domestic bank international non-core FX funding (Avdjiev, McCauley and McGuire, 2012; Borio, McCauley and McGuire, 2011; Hahm, Shin and Shin, 2013). We show that CC tame credit booms because, by targeting foreign bank debt, they increase the effectiveness of domestic interest rate policy on credit supply. However, CC do not target domestic liquidity -e.g. bank deposits from local households and firms- that constitute the bulk of domestic bank funding. We show that domestic macroprudential policy via (tightening of) RR cuts credit supply by targeting domestic bank deposits. The increase in RR on domestic deposits directly reduces credit supply during the boom, and more so for riskier firms, rather than (indirectly) enhancing the effects of local monetary rates on credit supply. ${ }^{13}$

Overall, our results innovate the literature on macroprudential policy (see e.g. Galati and Moessner, 2013; 2018) by suggesting a "prudential Tinbergen rule" for tackling booms driven by a combination of domestic and foreign liquidity that is used by different financial intermediaries for financing their lending activities. Two instruments, i.e. CC and one domestic prudential measure $-\mathrm{RR}$ in our Colombian episode- are necessary to tackle the two (intermediate) objectives (sources of liquidity).

\footnotetext{
${ }^{12}$ For evidence on deviations from CIP in both Advanced and Emerging Economies, see e.g. Borio, McCauley and McGuire, 2016; Cerutti, Obstfeld and Zhou, 2019; Du and Schreger, 2016; Du, Tepper and Verdelhan, 2018.

${ }^{13}$ We analyze CC in conjunction with other domestic RR-policies, highlighting different channels of transmissions to credit supply, whereas most existing studies focus on just one of the two policies. For evidence on the effectiveness of prudential RR, see, among others, Barroso et al. (2020), Cordella et al. (2014) and Federico, Vegh and Vuletin (2014).
} 
The rest of the paper is organized as follows. Section 2 describes the two policy changes and the datasets. Section 3 presents the results on the bank lending channel of monetary policy. In Section 4, we discuss findings on domestic reserve requirements. Section 5 briefly concludes.

\section{Institutional Settings and Data}

\subsection{Capital Controls on Capital Inflows and Reserve Requirements Policy in Colombia}

The Colombian economy expanded rapidly in the mid-2000s, with annual GDP growth above 4 percent in both 2004 and 2005. At least from early 2006, inflationary pressures further intensified due to a pronounced surge in domestic credit. The annual growth rate of commercial credit more than doubled in 2006- from less than 10 percent to 22 percent (Figure 2, Panel A). The Central Bank reacted by steadily increasing the interest rate, from 6 percent at the end of 2005 to 8 percent by early 2007 and further up to 10 percent in mid-2008. A higher monetary policy rate was accompanied by a widening interest rate differential vis-à-vis the U.S. Fed Funds Rate as early as mid-2006 (Figure 2, Panel B). These developments triggered strong capital inflows - especially non-FDI debt inflows - by third quarter 2006 (and peaking in first quarter 2007 just before the introduction of capital controls), as well as an associated sharp appreciation of the Peso-USD nominal exchange rate.

To deal with the acceleration of domestic credit boom, financed in part with foreign liquidity, the Central Bank resorted to a package of unconventional prudential measures on May $7^{\text {th }}, 2007$.

\section{[Insert Figure 2 here]}

First, Capital Controls were introduced in the form of an Unremunerated Reserve Requirement (URR) on all new FX debt inflows. ${ }^{14}$ The URR works as follows: upon disbursement of the FX credit to a Colombian firm (either a bank or a nonfinancial company), 40 percent of the nominal loan amount is deposited in an account at the Central Bank, with no remuneration in return. The deposit is always borne by the ultimate borrower of the debt and can be withdrawn without penalty only after six months. At the time, local interest rates -as reflected

\footnotetext{
${ }^{14}$ Portfolio inflows were initially excluded, but eventually made subject to the URR just one week after. On the contrary, foreign direct investments (FDI) were not subject to the URR, though in May 2008 a minimum stay of 2 years was applied to FDI.
} 
by the overnight interbank rate- were as high as 8.4 percent. The new regulation resulted in high taxation of FX debt inflows. ${ }^{15} \mathrm{CC}$ were borne by the banks to the extent that FX funding was raised to finance peso investments, including lending. When bank FX funding finances FX lending, it is the bank's customer that pays the CC (to avoid double taxation of capital inflows, bank FX funding is exempted). ${ }^{16}$ In this paper, we focus on the impact of CC on domestic credit through a bank-financing channel, where most firms in Colombia are small and medium sized enterprises (SMEs) without access to FX corporate debt. ${ }^{17}$ Finally, CC were lifted by October 2008 amid signs of an economic slowdown related to the unfolding of the GFC after Lehman's collapse. Moreover, joint with CC, the Central Bank introduced an upper bound on the banks' gross FX-position (i.e. the sum of on- and off-balance-sheet FX assets and liabilities), equal to $500 \%$ of banks regulatory capital. This constrained further banks' ability to access FX-financing.

Contemporaneously with the $\mathrm{CC}$, the Central Bank also modified its policy on Reserves Requirements (RR) on bank domestic financing. In May 2007 the Central Bank introduced a marginal RR on bank deposits, to be applied on top of the ordinary reserve requirements to new deposits received after May $7^{\text {th }}, 2007$. In other terms, the marginal RR would only apply on the increase in total bank deposits after May $7^{\text {th }}, 2007$. The marginal RR was not remunerated (at a time of high local interest rates) and was fixed at 27 percent for checking deposits and 12 percent for savings deposits. At the time of the introduction of the marginal RR, the level of ordinary RR was 12 percent and 6 percent for checking and savings deposits, but it was eventually raised to 8.3 percent just one month later in June 2007 - contemporaneously, the marginal RR was set at 27 percent for both savings and checking deposits. The marginal RR was eliminated in August $2008 .^{18}$

\footnotetext{
${ }^{15}$ Earlier withdrawals were allowed with the payment of a heavy penalty. The penalty decreased in time and ranged from 9.4 percent of the deposit in the first month to 1.6 percent during the sixth and last month.

${ }^{16}$ Colombian banks and banks from other countries that follow Basel capital rules basically fully hedge their FX exposure.

${ }^{17}$ In a related paper (Fabiani et al., 2021), we analyze the effects of CC directly borne by non-financial companies, focusing in particular on the subsample of roughly 1,200 (large and export-oriented) firms issuing FX-debt without credit intermediation by banks operating in Colombia. For comparison, the largest sample in this paper comprehends 110,226 companies.

${ }^{18}$ In 2007, regulators also introduced changes with respect to loan provisions. Countercyclical loan provisions were introduced in July 2007 and the criteria was that each financial institution must accumulate or deplete its countercyclical provisions according to four criteria: deterioration of portfolio, efficiency, fragility and loan growth. In addition, in May 2007, there was a change in the rule for computing banks' loan losses provisions, based on expected rather than incurred losses. Throughout the paper, we show that our findings are not significantly affected by such policy change (whose effects are investigated by López, Tenjo and Zárate, 2014, and Morais et al., 2020).
} 


\subsection{Data and Summary Statistics}

Our work is based on two administrative datasets provided by the Colombian Financial Supervisory Authority (Superintendencia Financiera de Colombia). First, we have access to the National Credit Registry (CR), which collects detailed quarterly information at the loan level for corporate loans, with information on loan volume and other loan characteristics. ${ }^{19}$ The CR tracks information on the universe of commercial loans provided to nonfinancial companies. We aggregate loan-level data at the firm*bank level, by computing the total debt provided by a given bank to a company in a given year:quarter. Second, we have access to bank supervisory quarterly balance sheets, which include data on bank size, profitability, capitalization, nonperforming loans (NPL), and, most importantly for our purposes, the volume of the sources of bank financing taxed through RR and $\mathrm{CC}$, i.e. domestic deposits and foreign FX inflows, respectively. The two datasets are matched through unique banking group identifiers.

We report the summary statistics in Table 1 . In Panel A, we show the summary statistics for the largest sample we analyze throughout the paper, referring to regressions where we exploit time-variation to measure the unconditional impact of local monetary policy rate on bank credit. In this setting, we apply at most firm*bank fixed effects and bank controls. Therefore, the only requisite for a firm*bank pair to enter the sample is that it appears twice in the CR during the period of analysis 2005Q2-2008Q2. ${ }^{20}$ This leaves us with 110,226 companies and 40 banks, corresponding to 12 major banking groups. Throughout the different year:quarters, this sample accounts on average for about 90 percent of total commercial credit. ${ }^{21}$ Loan $_{\mathrm{f}, \mathrm{b}, \mathrm{yq}}$ is expressed as the $\log$ of total outstanding (end of quarter) firm-(f)*bank-(b) debt, expressed in Colombian

\footnotetext{
${ }^{19}$ For each loan, we observe the interest payments (not interest rates) to proxy for credit risk and an indicator for whether the maturity of the loan is less than one year to proxy for liquidity risk.

${ }^{20}$ Note: CC were removed in early October 2008, i.e. in 2008Q4. Nonetheless, we always stop our sample in 2008Q2 to avoid contaminating the effects of capital controls with those of the 2008-2009 Global Financial Crisis, which implied a sharp increase in the volatility of capital inflows (Forbes and Warnock, 2012) and which unfolded beyond the US borders after the failure of Lehman Brothers in mid-September 2008. All results on CC presented below are robust to the inclusion of observations for 2008Q3 in our samples. Moreover, our main results are even qualitatively robust (and, if anything, quantitatively stronger) after restricting the sample to 2007Q3, despite the significant reduction in the heterogeneity in monetary policy rates and banks' FX-financing (note that the Colombian central bank was raising the interest rate during this period). Additional cross-country (time-series) analysis based on BIS data shows that credit in Colombia slowed down significantly after 2007Q2, relatively to other Emerging Economies, including their subsample from Latin America. Results based on different samples (either shorter or longer) are available upon request.

${ }^{21}$ We exclude both financial companies and public utilities from the analysis, which roughly account for $10 \%$ of total commercial credit.
} 
pesos as of 2005Q1. To get a sense of the magnitude of loans, the average loan is roughly 8,500 USD as of 2005Q1. There are large differences in loan size across companies, though. A one interquartile variation in loan size reflects larger loans by more than 40,000USD as of 2005Q1.

Throughout our period of analysis, the monetary policy rate, labelled as $\mathrm{i}_{\mathrm{yq}-1}$, is close to 7.5 percent on average. We also employ other measures of interest rate policy, including the growth of the local policy rate over a half year and over one year. Additionally, we use Taylor rate residuals, derived from two different rules: one expressing the policy rate as a function of the lagged yearly inflation rate and output gap (Rule 1), and the other as a function of yearly inflation and log GDP (Rule 2). A further important measure in our analysis is given by the spread between the local policy rate and the effective US FED Funds Rate, i.e. MPspread ${ }_{\text {yq-1. }}$ Throughout the period of analysis, the spread is constantly positive and is about 3 percent on average. The distribution of the spread between the 3-month sovereign Colombian and U.S.

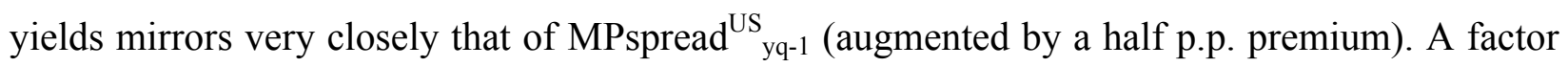
explaining the sovereign spread may be deviations from the CIP. Although the largest deviations are observed after the Financial Crisis (see, e.g., Borio et al., 2016), they are still significant throughout our period of analysis and amount on average to 17 percent of the mean sovereign yield spread. ${ }^{22}$ Finally, throughout all regressions on monetary policy rates, we apply further lagged macro controls, namely the annual growth rate of GDP, the lagged CPI index with base in 2005Q1 and the log Peso-USD exchange rate (expressed as Colombian Pesos per 1USD, so that an increase corresponds to a depreciation of the local currency). ${ }^{23}$

[Insert Table 1 here]

\footnotetext{
${ }^{22}$ The deviations from the CIP are retrieved from Du and Schreger (2016). In particular, they note that - absent CIP deviations - at a given tenor, the Colombia-US sovereign yield spread should equal the forward premium applied on a cross-currency swap that: i) buys U.S. zero-coupon Treasuries out of Colombian Peso; and ii) allows later on to enjoy the cash flows from US Treasuries in Colombian Pesos. Hence, they compute such forward premium (labelled as $\mathrm{FP}_{\mathrm{yq}-1}$ in Panel B of Table 1) and subtract it from the Colombia-U.S. Sovereign yield spread, obtaining a series of deviations from the CIP. Du and Schreger (2016) compute those deviations for different sovereign bond tenors. We retain data for the 3-month tenor for two reasons. First, such data are available throughout the entire period of analysis for Colombia. Second, there is a tight link between the Colombian-US monetary policy rate spread and the 3 -month sovereign yield spread. We aggregate data at the quarterly level by taking the average of the daily values.

${ }^{23}$ The Peso-USD exchange rate substantially correlates with both the VIX, reflecting the large influence of global liquidity conditions on the Colombian external sector, and with the oil price - which we alternatively use in some regressions - reflecting Colombia's dependence on oil exports.
} 
Panel B shows summary statistics for the smaller sample we focus on for the investigation of carry trade lending strategies triggered by variations in the local monetary policy rate. In this framework, we saturate the model with firm*year:quarter fixed effects, which excludes companies borrowing from one bank only in a given year:quarter, explaining the drop in observations with respect to Panel A. Note that companies with multiple lending relationships are typically larger, reflected by the fact that average loan size almost doubles. Indeed, the smaller sample of 37,867 multibank companies in Panel B represents a very large share of total commercial credit, close to 80 percent on average in our period (and, in turn, 90 percent of the aggregate credit in the sample of Panel A). Credit supply channels identified from regressions run over this sample therefore provide a representative picture of macroeconomic developments in bank credit. Regarding bank-level variables, the average FX indebtedness, denoted by FXFunds $_{\mathrm{b}, \mathrm{yq}-1}$, equals 4.6 percent of total assets in the period from 2005Q2 to 2008Q2. This is a relatively large figure, larger for instance than the average common equity capital $\left(\mathrm{CET}_{\mathrm{b}, \mathrm{yq}-1}\right)$ over the same period, and more than half of the minimum threshold for regulatory capital (summing up Tier 1 and Tier 2 capital), fixed at 9 percent of total assets.

Importantly, the distribution of bank FX-Funds $\mathrm{b}_{\mathrm{b}, \mathrm{q}-1}$ displays large heterogeneity, with a s.d. of 2.59 p.p. Nonetheless, the bulk of bank liabilities is given by domestic liquidity. In particular, savings deposits, denoted by the variable $S a v i n g D_{b, y q-1}$, finance on average more than a third of a bank's total assets, whereas checking deposits (i.e. current accounts) -represented by the variable Checking $\mathrm{D}_{\mathrm{b}, \mathrm{yq}-1}$ - fund 13.6 percent of total assets on average. Further, we have data on bank size (i.e. log total assets), nonperforming loans (i.e. loans at least 30 days past due, accounting on average for 2.7 percent of total loan volume at the bank level), and return on assets, which are quite homogenously distributed across banks and equal 1.4 percent on average on a quarterly basis.

Finally, for analyzing risk-taking associated with carry trade lending, we build various indicators of firm-level riskiness and opaqueness. First, we proxy credit risk through the average yield paid by a company over the pre-policy period 2005Q1 to 2007Q1, proxied through interest payments (rescaled by loan size) and denoted by Firm Risk $\mathrm{f}_{\text {,pre. }}$. This is computed by taking, in each year:quarter, the weighted average of the loan-level "yields", with weights given by the loan shares relative to the total volume of bank debt at the firm level. Next, we take a firm-level 
average across the period 2005Q1 to 2007Q1. Note that an interquartile variation in such a variable corresponds to a 6.1 p.p. increase in the average firm-level yield, i.e. a 43 percent increase relative to the mean value, which we interpret as a sizable magnification of credit risk. The average reliance on short-term debt is computed with an analogous procedure, which is based on a 0/1 dummy for whether a loan has maturity no longer than one year. Companies rely on short-term debt for roughly one third of their total borrowing on average. The distribution, however, reveals significant differences across firms. A one interquartile variation implies higher reliance on short-term debt by a factor of 46.8 p.p. Firms in the fourth quartile of the distribution have more than half of their total debt with outstanding maturity below or equal to one year. These figures reflect large heterogeneity in refinancing risk across companies. As an additional measure for firm (default) risk, we also build a dummy with a value of 1 if a company has one or more loans with payments at least 30 days past due over the period 2005Q1 to 2007Q1, and 0 otherwise. In fact, the average value for this dummy shows that roughly 30 percent of the loans in our sample are granted to firms with such past due payments. Finally, a firm's opaqueness is proxied by a $0 / 1$ dummy for whether a company's balance sheet is supervised by a public authority or not in the pre-policy period, ${ }^{24}$ under the implicit assumption that balance sheet disclosure enhances firm transparency. Supervised companies represent about 10 percent of the firms in our sample, but they nonetheless account for about 30 percent of the loans, suggesting that those firms are larger and have more relationships in place with banks operating in Colombia.

Panel C reports the summary statistics for the sample we consider in the analysis of the RR policy. In this case, we run a traditional difference-in-differences exercise, comparing the evolution of bank credit before and after the introduction of the policy across differently exposed banks. Since shocks to the RR take place over the period 2007Q2-2008Q2, we build symmetric pre/post five quarter windows by running regressions over the year:quarters from 2006Q1 to 2008Q2. Again, as we isolate credit supply channels by saturating the model with firm*year:quarter fixed effects, the sample includes companies with at least two banking relationships in each year:quarter. To measure a bank's exposure to the RR shocks, we fix bank-

\footnotetext{
24 Companies with sufficiently large size, as measured by total assets, must disclose their balance sheet to Colombia's Authority for Supervision of Corporations (Superintendencia de Sociedades). Such data are also publicly available at the Authority's website.
} 
level variables at their 2007Q1 value, the year:quarter preceding the shocks. We consider both savings and checking deposits alone, and their sum, denoted by the variable RR-Depo $\mathrm{o}_{\mathrm{b}, 2007 \mathrm{Q} 1}$, which provides a measure of a bank's overall reliance on the liabilities targeted through the RR policy. The sum of checking and saving deposits accounts for nearly half of bank total assets in 2007Q1. In general, the distribution of all bank balance sheet items in 2007Q1 is very similar to that described above for the longer period 2005Q2-2008Q2, suggesting a substantial stickiness in bank capital structure.

\section{Capital Controls and the Bank-Lending Channel of Monetary Policy}

\subsection{Empirical Strategy}

We first investigate the transmission of the spread between the local policy rate and the US Effective Federal Funds Rate to bank credit through the lens of a loan-level regression model which exploits time variation over the period 2005Q2-2008Q2 within a given firm-bank pair. The most robust version of the model follows:

$$
\begin{aligned}
\text { Loan }_{\mathrm{f}, \mathrm{b}, \mathrm{yq}}= & \beta_{1} \text { MPspread }_{\mathrm{yq}-1}^{\mathrm{US}}+\beta_{2} \text { Post }_{\mathrm{yq}}+\beta_{3} \text { Post }_{\mathrm{yq}}{ }^{*} \text { MPspread }_{\mathrm{yq}-1}^{\mathrm{US}}+\gamma_{1} \text { MacroControls }_{\mathrm{yq}-1}+ \\
& \gamma_{2} \text { BankControls }_{\mathrm{b}, \mathrm{yq}-1}+\gamma_{3} \text { FirmCredit }_{\mathrm{f}, \mathrm{yq}-1}+\delta_{\mathrm{f}, \mathrm{b}}+\varepsilon_{\mathrm{f}, \mathrm{b}, \mathrm{yq}}
\end{aligned}
$$

The dependent variable (i.e. $\operatorname{Loan}_{\mathrm{f}, \mathrm{b}, \mathrm{yq}}$ ) is the log total volume of outstanding debt provided by bank $b$ to firm $f$ in year:quarter yq. The main coefficient of interest is $\beta_{3}$, describing the additional marginal effect of the lagged Colombia-vs-US policy rate spread MPspread $\mathrm{yq}_{\mathrm{yq}-1}^{\mathrm{US}}$ on bank credit after the enforcement of $\mathrm{CC}$ and $\mathrm{RR}$, on top of the pre-policy marginal effect, captured by $\beta_{1}$. In the baseline versions of the model, we apply the policy rate spread between Colombia and US because this difference determines the profitability of a carry-trade strategy in which investors borrow in USD and lend in pesos. In fact, in the next subsection, we will show that such mechanism is key for explaining the relation between macroprudential policies, especially capital controls, and the bank lending channel of monetary policy. Nonetheless, we also eventually estimate models replacing the monetary policy rate spread with the lagged Colombian policy rate, i.e. $\mathrm{i}_{\mathrm{yq}-1}$. In either case, we apply a lagged (by one-quarter) proxy of monetary policy rate. Using the lagged (instead of the contemporaneous) monetary policy rate is aimed at attenuating reverse causality concerns about the relation between the dynamics of 
domestic credit and monetary policy rates and is common practice in the empirical literature on the bank lending channel of monetary policy (see, e.g., Ongena et al., 2021, for a recent contribution). Post $\mathrm{yq}_{\mathrm{q}}$ is a dummy variable with value 1 from 2007Q2 onward and with value 0 before.

As the monetary policy rate is influenced by macroeconomic developments, which can affect bank credit as well, we include a vector of macro controls, MacroControls $\mathrm{yq}_{\mathrm{yq}-1}$, which may determine the Central Bank's policy reaction function. The Colombian monetary policy rate is formally governed by a pure inflation targeting regime so that we employ the lagged annual GDP growth rate and level of price, proxied by the CPI. Moreover, we add the lagged log exchange rate, controlling for the eventual influences of external factors (e.g. the dynamics of the Balance of Payments) on the local policy rate. This implies that the component of the monetary policy rates (and of the spread) which contributes to our estimates is akin to a Taylor residual for a small open economy in which the Central bank responds to changing GDP and inflation dynamics and, potentially, also to movements in the exchange rate.

The model is further augmented with a vector of lagged bank controls, consisting of bank FX funding, savings and checking deposits, size, ROA, common equity, and NPLs. These vector of bank-level variables is meant to control for bank balance sheet items which the previous literature on the bank-lending channel of monetary policy (dating back to Bernanke and Gertler, 1995) has shown to significantly interact with variation in the policy rate. Moreover, we also control for lagged total firm credit as a proxy for firm leverage, ${ }^{25}$ as companies with different levels of leverage respond differently to macroeconomic and monetary policy changes (see, e.g., Caglio et al., 2021).We saturate the model with firm*bank fixed effects, denoted by $\delta_{\mathrm{f}, \mathrm{b}}$, which take care of all (observed and unobserved) time-invariant heterogeneity at the level of the single lending relationship. Finally, $\varepsilon_{\mathrm{f}, \mathrm{b}, \mathrm{yq}}$ is an error term. We double-cluster standard errors at the firm and bank*(four-digit SIC)-industry level, a convention we maintain throughout the paper. Hence, we allow for correlation of the error-term both within-borrower (across time and lenders) and within-lender (across time and firms of a given industry). ${ }^{26}$

\footnotetext{
${ }^{25}$ For most companies we do not observe total assets nor equity, so that we cannot compute the exact financial leverage, though we control for firm fixed effects.

${ }^{26}$ Clustering at the bank*industry level is economically sensible because changes in monetary policy rates affect different industries in different ways and because demand for credit is industry-specific. Moreover, from an
} 
Next, and most importantly, we estimate a model which sheds light over the influence of (ex ante sticky) banks' capital structure, especially the liabilities taxed either through CC (i.e., FXfunds) or through RR (i.e., domestic deposits), on the transmission of monetary policy rates on bank credit. Again, we present the most robust version of the model, estimated over the period 2005Q2-2008Q2:

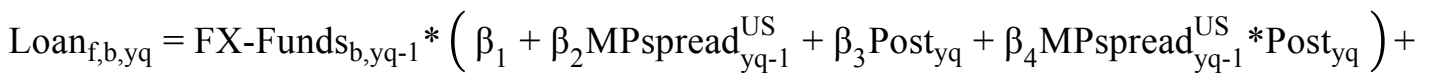

$$
\begin{aligned}
& \text { SavingD } D_{\mathrm{b}, \mathrm{yq}-1} *\left(\sigma_{1}+\sigma_{2} \text { MPspread }_{\mathrm{yq}-1}^{\mathrm{US}}+\sigma_{3} \text { Post }_{\mathrm{yq}}+\sigma_{4} \text { MPspread }_{\mathrm{yq}-1}^{\mathrm{US}} * \text { Post }_{\mathrm{yq}}\right)+ \\
& \text { CheckingD } D_{\mathrm{b}, \mathrm{yq}-1} *\left(\phi_{1}+\phi_{2} \operatorname{MPspread}_{\mathrm{yq}-1}^{\mathrm{US}}+\phi_{3} \text { Post }_{\mathrm{yq}}+\phi_{4} \text { MPspread }_{\mathrm{yq}-1}^{\mathrm{US}} * \text { Post }_{\mathrm{yq}}\right)+ \\
& \text { FX-Funds }_{\mathrm{b}, \mathrm{yq}-1} *\left(\mu_{1}+\mu_{2} \text { Macro }_{\mathrm{yq}-1}+\mu_{3} \text { Post }_{\mathrm{yq}}+\mu_{4} \text { Macro }_{\mathrm{yq}-1} * \text { Post }_{\mathrm{yq}}\right)+ \\
& \text { BankControls } *\left(\Gamma_{1}+\Gamma_{2} \text { MPspread }_{\mathrm{yq}-1}^{\mathrm{US}}+\Gamma_{3} \text { Post }_{\mathrm{yq}}+\Gamma_{4} \text { MPspread }_{\mathrm{yq}-1}^{\mathrm{US}} * \text { Post }_{\mathrm{yq}}\right)+ \\
& +\delta_{\mathrm{f}, \mathrm{b}}+\delta_{\mathrm{f}, \mathrm{yq}}+\varepsilon_{\mathrm{f}, \mathrm{b}, \mathrm{yq}}
\end{aligned}
$$

The dependent variable is the log total volume of outstanding debt provided by bank $b$ to firm $\mathrm{f}$ in year:quarter yq. We study how this variable reacts to variations in the local versus U.S. policy rate spread, depending on the banks' relative reliance on FX liabilities (affected by the $\mathrm{CC}$ ). As before, to better highlight the carry trade mechanism, we report in our main table results employing the policy rate spread, but we also show that results are robust if we use the simple lagged local policy rate.

The main coefficients of interest are $\beta_{2}$ and $\beta_{4}$. Under the carry trade hypothesis, $\beta_{2}$ is positive, as banks with higher FX funding lend more when the wedge between the policy rates goes up, while $\beta_{4}$ is negative, as $\mathrm{CC}$ break the carry by increasing the costs of FX funding, thereby reducing the gains associated with larger policy rate wedges.

We also horse race our carry trade mechanism against the alternative hypothesis that domestic deposit funding drives the different relation between loan volume and local monetary

econometric perspective, if we were to cluster standard errors at the bank level, we would be left with 12 clusters (due to the fact that bank balance sheet data are consolidated across major banking groups), which is strictly below the conventional threshold of 50 clusters (Cameron and Miller, 2015) which grant that asymptotic properties of the variance-covariance matrix estimator kick in. By taking the interaction of bank and industry dummies, we obtain 4,246 clusters. Moreover, we show in robustness checks that our results survive under more conservative clustering strategies, including triple-clustering at the firm, bank and time (i.e., year:quarter) level. 
policy rate before and after 2007Q2 ${ }^{27}$ We control as well for the interactions of bank FX funding with the other macro controls (and with the post-dummy), e.g. because variations of the exchange rate, which correlate with the MP-spread, might induce a different reaction in credit supply across differently FX exposed banks. Hence, following the discussion above, we can interpret $\beta_{2}$ and $\beta_{4}$ as the response of banks with higher FX-funding to a positive update in the policy rate spread captured by Taylor residuals which purge such spread from the influence of GDP growth, inflation and exchange rate growth. Moreover, we allow for all remaining bank characteristics to influence bank debt differently depending on the lagged level of the policy rate spread, before and after the enforcement of the policy (e.g. higher levels of bank capitalization are associated with credit expansions when the interest rate is relatively higher, Jiménez et al., 2012).

Finally, we saturate the model with firm*bank fixed effects, $\delta_{\mathrm{f}, \mathrm{b}}$, and, importantly, firm*year:quarter fixed effects, denoted by the parameters $\delta_{\text {f,yq }}$. Following Khwaja and Mian (2008) and Jiménez et al. (2012 and 2014), these fixed effects are crucial for the isolation of the bank lending channel of monetary policy, as they allow the comparison of the evolution of credit to the same firm in a given year:quarter in reaction to variations of the policy rate, depending on the different funding structures of the firm's lenders. In other terms, such fixed effects fully control for firm-level's time-varying demand shocks.

For easing the interpretation of the coefficients, all independent variables are demeaned. We always apply this convention throughout the paper.

\subsection{Results}

Column 1 of Table 2 shows the results from the estimation of the model in the largest available sample. In the pre-policy period, an increase in the monetary policy rate spread does not exert any significant effect on credit. After CC and RR are enforced, however, the relation becomes negative, which corresponds to an enhancement of the bank-lending channel. From a quantitative perspective, a 1 p.p. increase in the policy rate spread is associated to an ex-post decline in credit by 4.25 p.p., as compared to the pre-policy period. Put differently, the period of

\footnotetext{
${ }^{27}$ Formally, the simple sensitivity of $\beta_{2}$ and $\beta_{4}$ to the inclusion of the full interaction of domestic deposits with the interest rate spread and the post dummy does not prove itself that RR are key to strengthening the bank-lending channel of monetary policy. This would also require that the coefficients $\sigma_{2}, \phi_{2}, \sigma_{4}$ and $\phi_{4}$ are statistically significant.
} 
enforcement of $\mathrm{CC}$ and $\mathrm{RR}$ is characterized by an economically meaningful strengthening of the relation between the monetary policy spread and credit. In column 2 , we estimate the model in the smaller sample of firms with multiple lending relationships, resulting from the eventual application of firm*year:quarter fixed effects. Results are both qualitatively and quantitatively robust.

In column 3, we start testing the carry trade mechanism by fully interacting bank FX funding with the lagged interest rate spread and the post dummy. ${ }^{28}$ In this regression, we control for time-varying macro-economic shocks by including year:quarter fixed effects. This allows us to absorb the average (unconditional) effect of the policy rate spread and focus on the cross-sectional response across banks that rely differently on FX-funds. We also control for the full interaction of banks FX funding with the other macro controls, and allow other bank characteristics to exert a different, unconditional, impact on credit before and after the introduction of the prudential measures in 2007Q2.

In line with carry trade lending strategies, $\beta_{2}$ is positive and $\beta_{4}$ is negative. That is, before $\mathrm{CC}$, banks with higher share of FX funds expand credit relatively more when the spread goes up, while after $\mathrm{CC}$ they reduce lending in reaction to a positive variation of the spread. Interestingly, an increase in the monetary policy interest rate spread amplifies an average positive effect of FXfunds on credit under capital mobility, and a negative one after the imposition of capital controls: notice, in fact, that the coefficients $\beta_{1}$ and $\beta_{3}$ are positive and negative, respectively.

In column 4, we take a first serious step in the direction of isolating credit supply channels by augmenting the model with industry (four-digit SIC)*year:quarter shocks, but the resulting variation in coefficients is minimal. In column 5, we finally introduce firm*year:quarter fixed effects, therefore fully controlling for time-varying firm-level idiosyncratic demand shocks. If anything, the magnitude of the coefficients $\beta_{2}$ and $\beta_{4}$ increases.

Finally, in column 6, we report the most robust version of the model where we additionally interact all the banks characteristics with the policy rate spread and with the post dummy.

\footnotetext{
${ }^{28}$ In column 3, there is an increase in the number of observations with respect to column 2, due to the fact that we do not control anymore for firm lagged credit. Indeed, once we interact banks FX-funding with the policy rate spread and the macro-controls, firm lagged credit has not a tangible impact on our estimates, so that we prefer to retrieve the maximum number of observations. Moreover, in the most robust version of the carry-trade regressions where we use firm*year:quarter fixed effects, firm credit would be anyway absorbed (like any other firm-level variable).
} 
Validating the carry trade mechanism, $\beta_{2}$ and $\beta_{4}$ are further strengthened. Importantly, the impact of carry trade lending strategies on bank domestic credit is both statistically and economically significant. In reaction to a 1 p.p. jump in the policy rate spread, before $\mathrm{CC}$, banks with a 1 s.d. (i.e. 2.6 p.p., see Table 1) higher share of FX funds expand credit supply in relative terms by 3.8 p.p.. After CC, however, the same combination of spread-increase and larger FX funding is associated with a relative reduction in credit supply by 7.3 p.p. (as compared to the ex-ante effect of interacted FX funds and policy rate spread), resulting in an overall statistically significant contraction of credit supply by 3.5 p.p.. ${ }^{29}$ The application of CC therefore sharply reduces carry trade incentives and contributes to restoring a negative relation between local policy rate variations and credit among highly FX indebted banks.

Differently, as shown in the Table A6 in the Appendix, whereby we display the horse race between the FX and the RR taxed liabilities, the interaction of the latter domestic liabilities with the policy rate spread (and the post dummy) is not significant. The same result holds in column 2 of Table D4 in the Online Appendix if, instead of interacting saving and checking deposits with the policy rate spread and the post dummy, we do interact the sum of the two (i.e., the variable RR-Depo ${ }_{b, y q-1}$ ), which is a proxy of bank-level overall exposure to the RR-shock. These findings indicate that the change in RR-policy did not contribute to strengthening the bank-lending channel of monetary policy rates.

\subsection{Robustness}

\subsubsection{The (Unconditional) Effect of Monetary Policy Rates on Bank Credit}

To start with, we perform a variety of robustness checks to validate that the key in columns 1 and 2 of Table 2 - namely, the influence of monetary policy rates on credit is generally more negative after the introduction of $\mathrm{CC}$ - is not sensitive to alternative model specifications. First, in Panel A of Appendix Table A3, we report coefficients under progressively saturated versions

\footnotetext{
${ }^{29}$ The statistical significance of the overall negative effect partially depends on the level at which we cluster standard errors, as one can see in columns 7 to 9 of Table 3. However, an insignificant total (ex-post + ex-ante) effect of monetary policy rates conditional on banks FX-funding is still a result suggesting a stronger monetary policy rates transmission on credit supply under capital controls. As a matter of fact, this implies that with capital controls in place banks are not able anymore to arbitrage jumps in monetary policy rates by borrowing in FX and lending in peso, which contributes to sharpening the pass-through of monetary policy rates on credit supply (i.e., the FX funding channel does not matter anymore).
} 
of the model. In particular, in column 1, we employ just firm fixed effects, needed as a minimal set of controls to account for differences in the size of loans across firms. Next, we augment the model progressively introducing macroeconomic controls (column 2), bank fixed effects (column 3), firm*bank fixed effects (column 4), bank controls (column 5) and a lagged proxy of firm leverage (column 6). Importantly, under all such different model specifications, our main coefficient of interest $\beta_{3}$ is negative and statistically significant at the $1 \%$ level. In other terms, irrespective of the model we consider, the results suggest that the introduction of the prudential measures contribute to strengthening the bank-lending channel of monetary (interest rate) policy. Moreover, post-estimation diagnostics suggest that under most model specifications, including importantly the most robust one in column 6, the overall ex-post effect of an increase in monetary policy rate spread (i.e., $\beta_{1}+\beta_{3}$ ) is negative.

In Panel B of Appendix Table A3 we report results from otherwise identical regressions in which we replace the lagged Colombia-vs-US policy rate spread with the simple Colombian policy rate, i.e. $\mathrm{i}_{\mathrm{yq}-1}$. As a matter of fact, also in this case, irrespectively of the model we consider, the relation between the policy rate and credit during the period of enforcement of CC and RR is more negative (as compared to the pre-policy period), that is, $\beta_{3}<0$. In particular, estimates of the fully saturated equation in column 6 suggest that: in the pre-policy period there is not a statistically significant relation between the lagged policy rate and credit; ex-post, however, a 1 p.p. jump in the local policy rate is linked to a relative cut in credit by 3.462 p.p..

Moreover, in Appendix Table A4, we further augment the most robust model with additional controls and/or fixed effects and we validate the robustness of our findings to alternative clustering of the standard errors. In Panel A, we report results for regressions using the monetary policy rate spread, whereas in Panel B we employ the simple Colombian policy rate. As results are nearly identical using either proxy of monetary policy rates, we just comment results using the policy rate spread in Panel A. In column 1, we include a linear time trend to verify that our findings are not contaminated by a general upward or downward path for credit, over a period of in which the Colombian monetary policy rate is generally on the rise. Indeed, results are virtually identical. There may be concerns that the described effect of Colombian monetary policy rate reflects changing global risk aversion. Hence, in column 2, we control directly for US monetary policy rate augmenting the mode with the Effective Federal Funds Rate (EFFR), an important 
exogenous driver of risk aversion worldwide (see, e.g. Bruno and Shin, 2015b). In column 3, we include a country-specific indicator of risk aversion, i.e. the JP-Morgan Emerging Market Bond Index (EMBI) for Colombia. ${ }^{30}$ In both models, the effect of the policy rate spread on credit remain insignificant before the introduction of CC and RR, and negative thereafter. In column 4, we saturate our equation with firm*quarter-of-the-year fixed effects (on top of firm*bank fixed effects), which account for firm-specific seasonal demand shocks for credit (Berg et al., 2021), which prompt a negative pre-policy response of credit to a rise in the policy rate spread, which is nonetheless reinforced after CC and RR are introduced.

In column 5, we additionally control for the lagged loan-level provision for losses, rescaled by the loan amount. Contemporarily to the prudential shocks, a modification of the accounting rules for computing loan loss provisions was introduced and we show that this does not interact significantly with our findings. In column 6, we rerun the baseline model weighting observation by the log loan size; the nearly unchanged coefficients reassure about the fact that baseline estimates do not reflect variations in very small loans. Likewise, applying the same weighting scheme to the demanding models controlling for firm* quarter-of-the year fixed effects and loan loss provisions does not alter our findings (column 7 and 8, respectively).

Finally, we estimate the baseline model under alternative clustering strategies at the level of firm and bank in column 7, firm and bank and year:quarter in column 8, and firm and bank*industry and year:quarter in column 9, and find that our coefficients of interest are nonetheless significant at conventional levels. Moreover, the overall ex-post effect of the monetary policy rate spread on credit (i.e., $\beta_{1}+\beta_{3}$ ) remains also negative and statistically significant at least at $10 \%$ level. $^{31}$

Next, in Appendix Table A5, we verify that these findings hold across different proxies of the monetary policy rates, including the half-year and yearly growth of the simple policy rate and two versions of Taylor residuals. Results are consistent and in line with those commented so far across the different proxies of local interest rate policy.

\footnotetext{
${ }^{30}$ The EMBI index is generally thought to be a good indicator of investors' risk appetite for Latin American assets and it does in fact respond to dynamics in global risk appetite and/or muting external sector conditions (see, e.g. Österholm and Zettelmeyer, 2008); similar considerations apply to its Colombian counterpart (Julio et al., 2013).

${ }^{31}$ In Panel A of Table D1 in the Online Appendix, results based on the policy rate spread and on the simple Colombian monetary policy rate are both robust also using bank-level clustering.
} 
Finally, we also pin down a dynamic loan-level response of bank credit to monetary policy rates by running local projections (Jordá, 2005). In practice, this amounts to sequentially estimating linear models which are otherwise identical to the one presented above, with dependent variable forwarded by $0,1,2$ and 3 quarters with respect to the independent variables; plotting the resulting coefficients then provides the impulse response functions (IRF) of bank credit to an increase in the monetary policy rates, shown in Figure D1 of the Online Appendix using either the policy rate spread between Colombia and US (Panel A) or the simple Colombian policy rate (Panel B). In both cases, the figures suggest that under capital mobility the effect of an increase in the policy rate is nil over the considered horizon (see the red IRF), whereas with $\mathrm{CC}$ in place there is a significant negative reaction at impact, which persists over the 3-quarter period following the innovation in monetary policy rates (see the blue IRF). ${ }^{32}$

\subsubsection{Monetary Policy Rates and Carry-Trade Lending}

In this subsection, we show that carry-trade lending induced by higher monetary policy rates is a robust result across a wide variety of modeling strategies and is not dependent on any specific choice presented so far.

In Table 3, we estimate alternative specifications of the model. In column 1, we further control for loan loss provisions, and their interaction with both the policy rate spread and the post dummy. In column 2, we rerun the baseline model (in column 6 of Table 2) with observations weighted by log loan size, so to allow our coefficients to be driven from more meaningful credit relationships. In column 3, we complement the WLS estimation with the full interaction of the loan loss provisions with the policy rate spread and the post dummy. In columns 4 to 6 , we estimate both by OLS and WLS the baseline model (and its augmented version with loan loss provisions), removing firm*year:quarter fixed effects and substituting them with industry*year:quarter fixed effects. This allows us to retrieve information on bank credit for companies borrowing from one bank only. Importantly, coefficients are virtually unaffected

\footnotetext{
${ }^{32}$ The local projections do not reproduce the typical hump-shaped form of impulse response functions, likely due to the fact that the short period at hand does not allow to observe the response at longer horizons where the effect of a change in the variable may mean revert.
} 
from all such modifications of our baseline model, so that both the qualitative and quantitative interpretation of our channel provided in the previous subsection go through. ${ }^{33}$

We estimate the baseline model under alternative clustering strategies at the level of firm and bank in column 7 , firm and bank and year:quarter in column 8 , firm and bank*industry and year:quarter in column 9 , and find that our coefficients of interest are nonetheless significant at conventional levels. ${ }^{34}$

\section{[Insert Table 3 here]}

Moreover, in Table D2 of the Online Appendix, we verify that our results our robust to alternative definitions of the bank-level variables. First, there may be worries about the fact that heterogeneity in bank-level variables reflect common changes across banks over time. Using time fixed effects, either alone or interacted with industry and firm dummies, already takes care of this concern to a large extent. In fact, if we explicitly subtract time fixed effects from banklevel variables (from separate bank-level regressions for each bank control on time fixed effects), we obtain nearly identical results, as evident in column 1. Second, while employing lagged values of bank-level variables ensures that bank balance sheet items are predetermined with respect to the dependent variable, one may argue that, setting their capital structure in a forwardlooking manner, banks FX-funding may be endogenously determined by future levels of lending. To address this issue, which does not seem especially worrisome in our context, given notable stickiness in banks' capital structure, ${ }^{35}$ we rerun our analysis using fully predetermined bank balance sheets (i.e., measured at their 2005q1 value) or fixed at their average level over the period of analysis. The results, reported in columns 2 and 3, suggest that both modifications do not alter our findings. Third, exploiting the ratio between FX-funding and assets, our findings may be capturing variations in bank size rather than heterogeneity in (ex-ante) reliance on FX-

\footnotetext{
${ }^{33}$ We further validate that our findings are robust to controlling for the full interaction of the policy rate spread and the post-dummy with an indicator for whether a bank is foreign-owned or not (the related regression table is available upon request). Indeed, our main coefficients of interest related to the carry-trade channel remain both qualitatively and quantitatively unchanged.

${ }^{34}$ In Panel B of Table D1 in the Online Appendix we show that our coefficients of interest are significant at conventional levels also under bank-level clustering.

${ }^{35}$ As a matter of fact, banks' capital structure is in fact very sticky over time. As a relevant example to this comment, bank fixed effects alone explain roughly $70 \%$ of the variation in FX-funding across banks (that is, $70 \%$ is the R-squared resulting from a bank-level regression of FX-funding on bank fixed effects, without any other control). This suggests that endogenous time-varying (and forward-looking) shocks to banks' FX-funding are not likely to alter our findings significantly, since they do not explain most of cross-sectional variation in FX-funding across banks.
} 
debt. This is unlikely to happen, as we do directly control for bank log total assets (interacted with both the policy rate spread and the post dummy). However, we test our model rescaling all bank-level ratios used as independent variables by either fully predetermined bank total assets as of 2005Q1 or average total assets over the period of analysis. Not surprisingly, results are robust to this sensitivity check (see, respectively, column 4 and 5).

We next examine the evolution of the carry trade lending mechanism over our period of analysis. In our regressions, we check the relative difference of the conditional response of FX indebted banks to the policy rate spread before and after the introduction of CC in 2007Q2. However, one might worry that the contraction in the strength of carry trade lending strategies that we attribute to the $\mathrm{CC}$ period might reflect a declining trend that took place before the introduction of CC. To address such concerns, we estimate the following model:

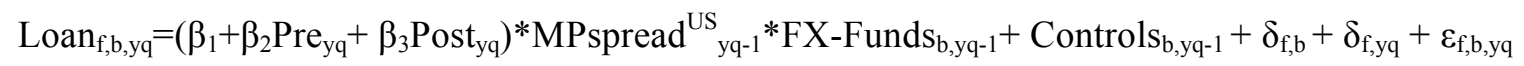

where: Pre $_{\mathrm{yq}}$ is a dummy with value 1 from 2006Q2 onward and 0 otherwise, whereas Post yq $_{\mathrm{q}}$ is our usual post-policy dummy with value 1 from 2007Q2 onwards. ${ }^{36}$ Under this specification: $\beta_{1}$ represents the intensity of the carry trade lending strategy during the period 2005Q2 to 2006Q1; $\beta_{2}$ estimates the intensity over 2006Q2-2007Q1 compared with the previous period; and finally, $\beta_{3}$ measures the change in the strength of carry trade lending over the CC-period 2007Q2-2008Q2 (relative to the period 2006Q2-2007Q1). We depict these three coefficients in Figure 3 . The coefficient $\beta_{1}$ is positive but barely statistically significant, whereas the larger and statistically significant coefficient $\beta_{2}$ suggests that the strongest period for carry trade has been 2006Q2-2007Q1.

\section{[Insert Figure 3 here]}

Finally, $\beta_{3}$ is strongly negative and statistically significant, ultimately suggesting that the contraction in carry trade lending before the policy cannot be attributed to preexisting trends. Moreover, the strengthening of the carry trade lending strategy over the period 2006Q2 to 2007Q1 is consistent with both aggregate and bank-level figures on FX inflows. Note in Figure

\footnotetext{
${ }^{36}$ Controls $_{\mathrm{b}, \mathrm{yq}-1}$ reflects the most robust version of the model, in which other balance sheet items are also fully interacted with MPspread ${ }_{\text {yq-1 }}^{\text {US }}$ (and both the Pre ${ }_{y q}$ and the Post ${ }_{y q}$ dummies) and FX-Funds $s_{b, y q-1}$ is further interacted with macro controls (and both the Pre $\mathrm{yq}_{\mathrm{q}}$ and the Post $\mathrm{yq}_{\mathrm{q}}$ dummies). $\delta_{\mathrm{f}, \mathrm{b}}$ and $\delta_{\mathrm{f}, \mathrm{yq}}$ denote firm*bank and firm*year:quarter fixed effects.
} 
2, Panel B, it is around 2006Q2 that Colombia has large (non-FDI) capital inflows associated with a higher policy rate which widens the spread with the U.S. Effective Federal Funds Rate. In Figure 4, we show the total quarterly FX debt intakes by Colombian banks (through long-term loans and bonds). ${ }^{37}$ Also in this more granular chart the capital boom ramps up at the end of 2006 and beginning of 2007 and is eventually halted by CC, therefore tightly mirroring the dynamics portrayed by our estimates.

\section{[Insert Figure 4 here]}

An especially important and interesting set of controls in our analysis is provided by the interaction of bank FX funding with proxies of conditions in the Colombian external sector, which might influence the ability of local banks to access FX liabilities as well as the value of such liabilities throughout time. In Table 4, we show our findings under alternative proxies. First, in column 1, we display the baseline model in column 6 of Table 4 , in which we use the $\log$ exchange rate (expressed as Colombian Pesos per 1 USD, so that an increase denotes a depreciation of the local currency). Interestingly, before $\mathrm{CC}$, a 1 s.d. appreciation of the exchange rate triggers a relatively larger increase in lending by 1 p.p. among banks with a 1 s.d. larger FX funding. However, under CC, this effect is not significant. In column 2, we replace the $\log$ exchange rate with the VIX, commonly interpreted as an indicator of global risk aversion (liquidity conditions) that significantly responds to U.S. monetary policy shocks (MirandaAgrippino and Rey, 2020) and drives capital flows worldwide (Rey, 2015). ${ }^{38}$ Our main coefficients of interest are robust to this replacement. Moreover, the interaction of the VIX with banks FX funding suggests that a 1 s.d. loosening in global risk aversion (decline in VIX) is associated with a relative jump in lending by 2.4 p.p. for banks with a 1 s.d. larger FX funding pre-CC. In line with results for the exchange rate, though, such influence is nullified by CC. In column 3, we use oil price as an indicator of external sector conditions for Colombia. Despite oil representing the bulk of Colombian exports, its price is largely determined by exogenous factors and comoves substantially with the exchange rate (over our period, by a factor of 80 percent).

\footnotetext{
${ }^{37}$ Importantly, they exclude FX-liabilities issued by Colombian banks through foreign subsidiaries and therefore significantly underestimates the extent of FX-borrowing.

${ }^{38}$ Reflecting a significant interdependence between the VIX indicator and external sector conditions in Colombia, the joint inclusion of the VIX and the exchange rate in a regression model generates multicollinearity issues. For this reason, we include the two variables in alternative models rather than together. Similar considerations apply to oil price, which is the main driver of Colombian exchange rates, given the prominent role of oil exports, and to the EMBI.
} 
Once again, the carry trade coefficients are not affected and a 1 s.d. increase in oil prices drives a relative expansion of lending by 5 p.p. for banks with a 1 s.d. larger FX funding, an influence halted by CC. Overall, these results are consistent with a mechanism such that when global conditions are loose, the value of bank FX liabilities increases and so does their credit supply (see, e.g., Bruno and Shin, 2015b). This channel is eventually broken by CC. Finally, in column 4, we apply the JP-Morgan EMBI index for Colombia, a proxy for investors' risk aversion for Colombian assets. Corroborating the results described so far, in the pre-policy period, a 1 s.d. decline in risk aversion (i.e., a decline in EMBI by 30 basis points) is associated to a relative expansion in credit supply for banks with a 1 s.d. higher FX funding by 1 p.p.. The introduction of CC nullifies this effect.

\section{[Insert Table 4 here]}

Additionally, we check in Table A7 in the Appendix that the carry trade channel is robust to substituting the policy rate spread with the simple policy rate. The coefficients from the most robust version of the model in column 6 imply that, before CC, banks with a 1.s.d. larger FX

funds respond to a 1 p.p. jump in the policy rate by increasing lending by 1.8 p.p.. Under CC, the same combination of policy rate increase and larger FX funding is associated with a relative lending cut by 2.5 p.p., as compared to the pre-policy effect, resulting in an overall cut in lending by 1.5 p.p..

Last, we analyze the dynamics of the carry-trade mechanism through local projections in Figure D2 of the Online Appendix. From a practical perspective, we use a specular model to the one analyzed so far, in which the dependent variable is however forwarded by $h$ quarters, $\mathrm{h}=0,1,2,3$ (as compared to the left-hand side variables). Plotting the resulting coefficients calibrated to a 1 p.p. increase in the policy rate spread and to a 1 s.d. higher bank FX-funding suggest that the carry-trade channel is operative at any horizon over the considered period. Once again, the lack of mean-reversion in the IRF is to be imputed to the (data-driven) short horizon over which we can estimate the reaction of credit to monetary policy rates.

\subsection{Dissecting the Carry Trade: Peso vs FX-Lending and CIP deviations}


In Table 5, we repeat our key exercise over a smaller sample of observations for which loan volume is broken down by currency, i.e. domestic (peso) and FX-lending. ${ }^{39}$ We consider peso and FX-loans separately in column 1 and 2, respectively. The coefficients clearly show that peso lending drives the results just described, which further corroborates the carry trade hypothesis.

While a carry trade strategy is in principle profitable also with FX loans (under the reasonable assumption that these are more expensive in Colombia than in global interbank and wholesale funding markets), the strategy will nonetheless grant higher returns through pesolending, given the positive policy rate differential. Also, banks would bear the CC tax only if FX funds were reinvested in peso-denominated assets, so that credit supply variations induced by CC must show up among peso loans. If banks borrow in FX to finance FX loans, the CC is borne by the ultimate borrower, i.e. a local company. As a result, the reduction in FX-loans associated with CC should show up as a demand shock in a loan level analysis, but we fully control for it by adding firm*year:quarter fixed effects (Khwaja and Mian, 2008). Finally, in column 3, the share of peso loans out of total bank debt also evolves according to the carry trade lending, although pre-policy carry is just marginally significant, and column 4 replicates the baseline analysis on total bank debt in this smaller sample by summing up peso and FX loans.

\section{[Insert Table 5 here]}

Moreover, we investigate the relation between the documented carry trade strategies by local banks and the deviations from CIP, computed over the 3-month yield spread between Colombia and U.S. sovereign bonds. Importantly, banks tend to fully hedge their FX borrowing. Hence, validating that our results are robust to substituting the policy rate spread with a proxy for CIP deviations is relevant, because such deviations grant returns from the carry even under fully hedged currency risk.

In Table 6 we report results from this exercise. We start by substituting the policy rate spread with the spread between the Colombian and U.S. sovereign 3-month yields. As already detailed in the data section, the two variables are very tightly linked, and in practical terms the sovereign spread corresponds to the policy rate differential plus a half p.p. premium. We repeat our

\footnotetext{
${ }^{39}$ We report the summary statistics for this smaller sample in Table A1 of the Appendix. Note that this sample consists of large companies with supervised balance sheets and accounts across time for 55 percent to 60 percent of the total loan volume for multibank nonfinancial companies in the regression sample in Table 2.
} 
regressions with the sovereign spread since the CIP-deviations retrieved from Du and Schreger (2016) are based on it. Indeed, results in column 1 of Table 6 confirm that carry trade lending strategies are operative also based on such 3-month sovereign spread. Quantitatively speaking, before the introduction of $\mathrm{CC}$, a 1 p.p. increase in the sovereign spread triggers a relative jump in credit supply of 2 p.p. by banks with a 1 s.d. higher FX funding. After the introduction of CC, however, the same combination of sovereign spread hike and higher banks FX funding leads to a 4.76 p.p. cut in credit supply (as compared to the ex-ante effect).

In column 2, we introduce the deviations from the CIP. Again, the coefficients are consistent with carry trade lending. That is, before (after) CC, higher CIP-deviations bring relatively larger (smaller) volumes of credit supply for more FX-exposed banks. A reasonable concern is that these results are confounded by the fact that CIP-deviations tend to be higher at times of relatively high sovereign spread, so that they do not necessarily reflect carries prompted by returns under full hedging of currency risk. For this reason, we perform an additional regression in column 3 in which we augment the model with the component of the 3-month sovereign spread which is not accounted for by CIP-deviations, namely the 3-month forward premium, $\mathrm{FP}_{\mathrm{yq}-1 .}$. We perform a full horse-race in which also this factor is fully interacted with not only bank FX funding, but also with the other bank controls. The resulting estimates suggest that the carry trade lending strategy is driven by both forward premia and CIP deviations. Nonetheless, CIP deviations exert a relatively greater influence on the dynamics of credit supply for FX indebted banks, suggesting that banks are relatively more inclined to pursue fully hedged carries (against FX risk). Absent CC, among banks with a 1 s.d. higher FX funding, a 1 p.p. increase in CIP deviations (forward premia) triggers an increase in credit by 3.5 p.p. (1.7 p.p.). With $\mathrm{CC}$ in place, the same combination of higher CIP deviations (forward premia) and bank FX funding leads to a 11.2 p.p (3 p.p.) relative decline in credit, as compared to the pre-policy effect. Finally, we replicate the analysis in column 4 with peso loans, in column 5 with FX loans and in column 6 with the share of peso loans as dependent variables. Consistent with our previous findings, higher CIP deviations (and forward premia as well, but less intensively) drive carry trade predominantly over peso loans for banks with relatively larger FX funding.

[Insert Table 6 here]

\subsection{Carry Trade and Risk-Taking: Heterogenous Effects across Firms}


We investigate whether carry trade lending heightens bank risk-taking, and the eventual influence of $\mathrm{CC}$ on it, by looking for heterogenous effects across companies, depending on their riskiness and opaqueness. In detail, we proxy for credit risk by sorting companies based on quartiles of the distribution of the average interest payments in the pre-policy period, i.e. Firm Risk $\mathrm{f}_{\text {fpre. }}$ An identical classification ranks firms by liquidity risk based on the distribution of the average pre-policy reliance on short-term debt, i.e. Short-Term Debt $\mathrm{f}_{\text {,pre }}$. Additionally, we split companies depending on whether they defaulted on at least one loan during the period 2005Q1-2007Q1, which further proxies for default risk. Finally, we divide companies by transparency and opaqueness based on whether their balance sheet is publicly supervised or not.

[Insert Table 7 here]

Table 7 reports estimates from the regressions on loan volume from the most robust version of the model. ${ }^{40}$ To start with, companies in the first quartile of credit risk (Firm Risk $\mathrm{f}_{\mathrm{f} \text {,pre }}$ ) are not impacted by the carry trade, neither before nor after $\mathrm{CC}$. On the contrary, firms with greater credit risk experience larger fluctuations in bank debt associated with the carry, and especially so for companies with above-median credit risk. For instance, in reaction to a 1 p.p. jump in the policy rate spread, before $\mathrm{CC}$, banks with a 1 s.d. higher share of FX funds expanded credit to firms in the fourth quartile of credit risk by 7.3 p.p. After CC, these firms also suffer sharper cuts, by 15.1 p.p. relatively to the pre-policy effect, resulting in an overall credit supply contraction by 7.8 p.p..

Similar dynamics apply to firms with different levels of liquidity risk. Indeed, carry trade lending does not affect bank debt of firms with the lowest liquidity risk, but significantly impacts loans to firms with higher reliance on short-term debt. Moreover, before CC, when the spread goes up by 1 p.p., companies that ex-ante default (do not default) on one or more loans enjoy a relative credit expansion of 5.1 p.p. (2.9 p.p.) by banks with a 1 s.d. higher share of FX funds; after CC, the same combination of jumps in the spread and in lenders' FX funds brings a relative

\footnotetext{
${ }^{40} \mathrm{We}$ choose to present results based on separate regressions for firms in different risk groups to ease the interpretation of our coefficients, based at most on triple interactions. However, in Panel A of Table D5 of the Online Appendix, we estimate pooled regressions for the firm risk results. The results are qualitatively and quantitatively similar. As a matter of fact, the fixed effects applied in these regressions (firm*bank and firm*time fixed effects) do not select different groups of firms depending on whether we run separate or pooled regressions; moreover, they imply within-firm estimation, so that the nearly identical results are not surprising.
} 
credit reduction of 9.7 p.p. (6.1 p.p.), as compared to the pre-policy effect, suggesting that both the credit expansion due to the carry and the $\mathrm{CC}$-induced cut are stronger among riskier companies. Finally, opaque firms do not benefit more than transparent ones from carry lending before $\mathrm{CC}$, but after their enforcement they undergo a much larger reduction in credit as compared to the ex-ante period with capital mobility, by 8.78 p.p. in response to the usual 1 p.p. increase in the spread and 1 s.d. jump in banks' FX exposure.

Overall, these findings are consistent with increased bank risk-taking due to carry trade lending. Also, they indicate that $\mathrm{CC}$ contribute to mitigating these risks, as the post-CC reduction in lending by highly FX indebted banks (following an interest rate spread increase) is concentrated among risky and opaque borrowers.

\section{The impact of Reserve-Requirements on Bank Credit}

In this section, we evaluate the impact of the shocks to RR on domestic deposits on bank credit. First, we present the empirical strategy. Second, we discuss the baseline findings. Third, we provide some robustness checks. Fourth, we check whether the impact of RR is heterogeneously distributed across firms. Last, we ask whether bank domestic deposits and foreign funding are substitutes or complements, ${ }^{41}$ which reveals whether RR and CC affect credit supply through distinct channels.

\subsection{Empirical Strategy}

We run a difference-in-differences exercise in symmetric five-quarter windows around the modification of the RR-policy in 2007Q2, i.e. over the period 2006Q1 to 2008Q2. We employ the following model:

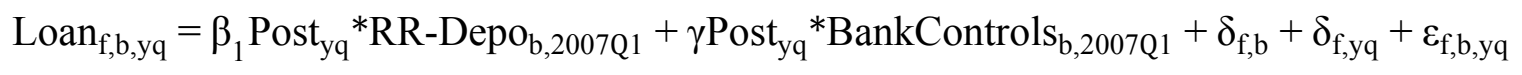

The dependent variable is loan volume. The main coefficient of interest is $\beta_{1}$, describing the impact of ex-ante heterogeneity in RR-taxed deposits, i.e. the sum of checking and saving deposits, on the ex-post volume of credit. Note that heterogeneity across bank reliance on deposits taxed by the RR-shock is taken as of 2007Q1, and an identical convention is applied to

\footnotetext{
${ }^{41}$ Note that the sum of domestic (saving and checking) deposits and FX-funding constitutes, on average, roughly 54 percent of banks' total assets. Hence, whether banks with a higher share of domestic deposits are more or less indebted in FX is ultimately an empirical question.
} 
bank controls. The model is augmented with firm*bank dummies, whereas firms' credit demand is controlled through firm*year:quarter fixed effects (Khwaja and Mian, 2008). $\varepsilon_{\mathrm{f}, \mathrm{b}, \mathrm{yq}}$ is an error term, double-clustered at the firm and bank*industry level.

The consistency of our estimates crucially depends on the parallel trend assumption: absent the modification of RR policy in 2007Q2, banks with different reliance on checking and savings deposits would experience parallel ex-ante and ex-post credit dynamics. We test the validity of such assumption in our setting using the alternative model:

$$
\text { Loan }_{\mathrm{f}, \mathrm{byq}}=\beta_{1, \mathrm{yq}} *\left(1[\text { year:quarter=yq] }) * \text { RR-Depo } \mathrm{b}_{\mathrm{b}, 2007 \mathrm{Q} 1}+\gamma \text { Post }_{\mathrm{yq}} * \text { Bank Controls }_{\mathrm{b}, 2007 \mathrm{Q} 1}+\delta_{\mathrm{f}, \mathrm{b}}+\delta_{\mathrm{f}, \mathrm{yq}}+\varepsilon_{\mathrm{f}, \mathrm{b}, \mathrm{yq}}\right.
$$

That is, we allow the relation between RR-Depo $\mathrm{b}_{\mathrm{b}, 2007 \mathrm{Q} 1}$ and loan volume to vary over the different year:quarters in our sample, as 1 [year:quarter=yq] is a dummy variable with value 1 in year:quarter yq and 0 otherwise. We fix 2007Q1 as the baseline period. A heuristic validation of the parallel trend assumption requires that the RR-treatment effect is zero before 2007Q2, and significant thereafter.

\subsection{Baseline Results}

\section{[Insert Table 8 here]}

We report baseline results in Table 8 . In column 1, we apply a minimal set of controls, including firm fixed effects and bank controls, interacted with the post dummy. The treatment effect is negative and significant at the 1 percent level. We next saturate the model, first by including firm*bank fixed effects, which imply an increase in the R-squared by roughly 30 p.p.. The treatment effect remains negative and significant (column 2). We then control for timevarying shocks, either common across all firms (column 3) or industry-specific (column 4), by applying year:quarter and industry*year:quarter fixed effects, respectively. Coefficients are virtually unaffected.

In column 5, we fully shut down firm demand shocks with firm*year:quarter fixed effects. The treatment effect remains significant at the 1 percent level, suggesting also a strong economic impact of RR-shock. A 1 s.d. (7.8 p.p.) increase in the share of total assets financed with either savings or checking deposits implies a 5.4 p.p. reduction in bank credit. In column 6, we test separately for the effect of checking and savings deposit exposures. The coefficients suggest a 
stronger effect of exposure to checking deposits, as a 1 s.d. (4.1 p.p.) jump implies a 7.6 p.p. reduction in loan volume. The effect of exposure to saving deposits is smaller, but nonetheless economically meaningful, corresponding to about 2.9 p.p. in reaction to a 1 s.d. (7 p.p.) increase.

\subsection{Robustness}

First, in Panel A of Table 9, we estimate alternative specifications of the model. In column 1, we further control for loan loss provisions, both alone and interacted with the post dummy. In column 2, we rerun the baseline model (from column 6 of Table 9) with observations weighted by log loan size to allow our coefficients to be driven from relatively larger credit relationships. In column 3, we complement the WLS estimation with loan loss provisions and their interaction with post dummy. In columns 4 to 6 , we estimate, both by OLS and WLS, the baseline model (and its augmented version with loan loss provisions), removing firm*year:quarter fixed effects and substituting industry*year:quarter fixed effects. This allows us to include in the regression sample those companies that borrow from only one bank. Importantly, coefficients are virtually unaffected by all such modifications of our baseline model, so that both the qualitative and quantitative interpretation of our channel provided in the previous subsection go through.

In columns 7, 8, and 9, we estimate the baseline model under alternative clustering strategies. In column 7, we estimate at the level of firm and bank. In column 8, firm and bank and year:quarter. And in column 9, firm and bank*industry and year:quarter. Our coefficients of interest remain significant at least at the 12 percent level in the case of firm and bank clustering. ${ }^{42}$

Second, we run cross-sectional regressions in which the dependent variable is the loan growth rate between 2007Q1 (the year:quarter before the shock to RR) and j quarters ahead, $\mathrm{j}=\{1,2,3,4,5\}$, to validate that the negative treatment effect persists across periods shorter than the

\footnotetext{
42 If we apply bank-level clustering, the significance level for the coefficient on RR-Depo $0_{b, 2007 Q 1}$ falls to just $19 \%$. Nonetheless, the effect of the increased taxation on checking deposits on credit supply is significant at $1 \%$ level (Panel C of Table D1 of the Online Appendix), which is reassuring given the larger economic significance of the coefficient on checking deposits (as compared to that for saving deposits) described in section 4.2 in the paper. The coefficient on checking deposits is likewise significant at conventional levels under double clustering at the firm and bank level (not shown). Recall, however, that clustering at the bank level raises issues about a small number of clusters (strictly below 50 ).
} 
five-quarter period we consider in the baseline finding. Results in Panel B of Table 9 suggest that this is the case.

\section{[Insert Figure 5 here]}

Third, we further inspect the validity of the parallel trend assumption. Figure 5 depicts the time-varying coefficient of the treatment effect (relative to a baseline, fixed at zero, for 2007Q1). Indeed, before 2007Q2, overall exposure to savings and checking deposits does not affect bank credit. After the RR shock, however, the coefficient becomes markedly negative and statistically different from zero, which provides suggestive evidence in favor of the parallel trend assumption being verified.

Fourth, we run a placebo test. That is, we consider a pre-policy sample from 2005Q1 to 2006Q4, and fix exposures and bank controls as of 2005Q4. This is a "fake" exposure, which should not be associated with a contraction in credit, which is confirmed in Panel C of Table 9. ${ }^{43}$

[Insert Table 9 here]

\subsection{Heterogenous Effects across Firms}

As with carry trade regressions, we sort companies according to proxies of credit risk, liquidity risk, default risk, and opaqueness, and repeat the baseline exercise across such different groups of firms. Table 10 displays the results.

[Insert Table 10 here]

The reduction in credit is not significant among firms with the lowest credit risk (those in the lowest quartile of the ex-ante distribution of average interest payments over loans). On the other hand, it is significant across riskier companies, and the reduction in credit among them increases as their riskiness does. In particular, firms in the upper quartile of credit risk experience a 15 p.p credit on loans from banks more RR-exposed by a 1 s.d. increase. Similarly, only companies with above-median liquidity risk suffer credit reduction from more RR-exposed financial institutions. Furthermore, there is not a statistically significant difference between companies with and without ex-ante loan defaults, but stark differences emerge between transparent companies and

\footnotetext{
${ }^{43}$ The summary statistics for the placebo test are in Table A2 of the Appendix.
} 
opaque companies. The former do not suffer any credit reductions due to RR shocks, whereas the latter suffer a 7.8 p.p. credit cut by lenders more exposed to RR by a 1 s.d. increase. ${ }^{44}$

\subsection{Banks’ Domestic and Foreign Funding: Complements or Substitutes?}

We have so far shown that: i) the bank-lending channel of monetary policy rates is strengthened by $\mathrm{CC}$, which affects bank foreign liquidity; ii) the shocks to RR exert a large direct negative effect on bank credit by raising the cost of core domestic liquidity. Both policies therefore contribute to taming credit booms. It remains to be understood whether the foreign and domestic liquidity are complements or substitutes in bank funding structure, i.e. whether banks that use more FX funds also employ larger core deposits to finance their assets, or not.

The scatterplot in Figure 1, which reports bank (time-varying, quarterly) reliance on savings and checking deposits on the x-axis and bank FX funds on the y-axis, indicates that banks that use more FX liquidity rely less on domestic core deposits. In other terms, banks more exposed to $\mathrm{RR}$ are less exposed to $\mathrm{CC}$, and over the period of analysis the two variables are correlated negatively (by a factor of 37 percent, significant at 1 percent level). ${ }^{45}$ A formal way to discern whether RR and the $\mathrm{CC}$ operate independently from each other is to directly horse race them in a regression model. In Table 11, we show results from such an exercise (run over the longer period from 2005Q2 to 2008Q2), in which we contemporarily employ the full interaction of the policy rate spread with banks FX funds and the post dummy, as well as the full interaction of the RRtaxed checking and savings deposits with the post dummy. ${ }^{46}$ In those regressions, both the decline in carry trade lending due to $\mathrm{CC}$ and in credit provided by banks more reliant on RRtaxed liabilities are significant, suggesting the two macroprudential policies operate independently from each other. ${ }^{47}$

[Insert Table 11 here]

\footnotetext{
${ }^{44}$ We obtain nearly identical results if, instead of running separate regressions for firms in different risk groups, we estimate a pooled model exploiting the triple interaction between the post dummy, the bank-level ex-ante exposure to RR and the different dummies for firm risk (see Panel B of Table D5 in the Online Appendix).

${ }^{45}$ For a more detailed view on the correlation across bank-level variables, both before and after removing time fixed effects, see respectively Panel A and B of Table D3 of the Online Appendix.

${ }^{46}$ Note that columns 1 through 4 in Table 11 correspond to columns 3 through 5 in Table 2 (check the carry trade coefficients). In Table 11, however, we explicitly show the effect of RR-taxed liabilities, before and after 2007q2.

${ }^{47}$ In column 1 of Table D4 of the Online Appendix the same result holds employing the sum of saving and checking deposits (i.e., RR-Depo $\mathrm{b}_{\mathrm{byq}-1}$ ) rather than the two separate variables.
} 
Put differently, $\mathrm{CC}$ and RR - i.e. macroprudential measures targeting foreign and domestic bank debt, respectively - affect bank credit supply through different channels, as banks more affected by $\mathrm{CC}$ are less impacted by RR, and vice versa. Both measures are therefore needed to slow down a boom driven by both foreign and domestic liquidity.

\section{Conclusions}

We analyze the effects of capital controls and macroprudential policy on credit supply exploiting: (i) the simultaneous introduction of capital controls and an increase of reserve requirements on domestic bank deposits in Colombia during a strong credit boom along with their cross-sectional implications across banks and loans/firms; and (ii) administrative credit registry and supervisory bank balance sheet data. In brief, we find the following robust results: first, banks use cheaper FX funding from abroad to arbitrage higher local monetary policy rates (which raises the policy rate spread against the U.S.), by carry trading cheap FX funds with expensive local lending, especially to ex-ante riskier, more opaque local firms. Capital controls, by taxing FX debt, reduce the interest rate differential and break the carry trade, enhancing the bank-lending channel of local monetary (interest rate) policy and reducing bank risk-taking. Second, the increase in reserve requirements on domestic deposits directly reduces credit supply during the boom, and more so for riskier firms, rather than (indirectly) enhancing the effects of monetary policy rates on credit supply.

Our main contribution to the literature is to show that both capital controls and (domestic) macroprudential policy tame credit supply booms, including credit supply to ex-ante riskier firms, by targeting different sources of bank debt. Capital controls target foreign bank debt, thereby improving the effectiveness of the bank lending channel of (local) monetary policy -by halting carry trade lending strategies by local banks- and domestic macroprudential policy targets local bank debt, directly attenuating credit supply booms. As credit booms stem from both foreign and local liquidity, and we find that reliance on domestic deposits versus foreign (FX) debt are very negatively correlated across banks (so that financial intermediaries more affected by capital controls are less impacted by reserve requirements, and the other way around), our results suggest that a Tinbergen rule with two (macroprudential) instruments is necessary to tackle the two (intermediate) objectives (sources of liquidity). 


\section{References}

Acharya, V.V., Imbierowicz, B., Steffen, S. and Teichmann, D. (2020). Does the lack of financial stability impair the transmission of monetary policy?. Journal of Financial Economics, 138(2), pp.342-365.

Acharya, V. V., \& Vij, S. (2016). Foreign currency borrowing of corporations as carry trades: Evidence from India. In NSE-NYU Conference on Indian Financial Markets (pp. 21-22).

Alam, Z., Alter, M. A., Eiseman, J., Gelos, M. R., Kang, M. H., Narita, M. M., ... \& Wang, N. (2019). Digging Deeper--Evidence on the Effects of Macroprudential Policies from a New Database. International Monetary Fund.

Avdjiev, S., Du, W., Koch, C., \& Shin, H. S. (2019). The dollar, bank leverage, and deviations from covered interest parity. American Economic Review: Insights, 1(2), 193-208.

Avdjiev, S., McCauley, R. N., \& McGuire, P. (2012). Rapid credit growth and international credit: challenges for Asia (No. w377). BIS Working Papers.

Barroso, J. B. R. B., Gonzalez, R. B., Peydró, J. L., \& Doornik, B. F. (2020). Countercyclical liquidity policy and credit cycles: Evidence from macroprudential and monetary policy in Brazil (No 1156). Barcelona GSE Working Papers.

Benigno, G., Chen, H., Otrok, C., Rebucci, A., \& Young, E. R. (2016). Optimal capital controls and real exchange rate policies: A pecuniary externality perspective. Journal of Monetary Economics, 84, 147-165.

Berg, T., Saunders, A., Schäfer, L., \& Steffen, S. (2021). Brexit and the contraction of syndicated lending. Journal of Financial Economics.

Bergant, K., Grigoli, F., Hansen, N. J., \& Sandri, D. (2020). Dampening global financial shocks: Can macroprudential regulation help (more than capital controls)?. (No w106). IMF Working Paper.

Bernanke, B. S., \& Gertler, M. (1995). Inside the black box: the credit channel of monetary policy transmission. Journal of Economic Perspectives, 9(4), 27-48.

Bianchi, J. (2011). Overborrowing and systemic externalities in the business cycle. American Economic Review, 101(7), 3400-3426.

Blanchard, O. (2013). Monetary policy will never be the same [Blog post]. Retrieved from: https://blogs.imf.org/2013/11/19/monetary-policy-will-never-be-the-same/.

Borio, C. E., McCauley, R. N., \& McGuire, P. (2011). Global credit and domestic credit booms. BIS Quarterly Review, September.

Borio, C. E., McCauley, R. N., McGuire, P., \& Sushko, V. (2016). Covered interest parity lost: understanding the cross-currency basis. BIS Quarterly Review, September. 
Bräuning, F. and Ivashina, V. (2020a). US monetary policy and emerging market credit cycles. Journal of Monetary Economics, 112, pp.57-76.

Bräuning, F. and Ivashina, V. (2020b). Monetary policy and global banking. The Journal of Finance, 75(6), pp.3055-3095.

Brunnermeier, M. K., \& Sannikov, Y. (2015). International credit flows and pecuniary externalities. American Economic Journal: Macroeconomics, 7(1), 297-338.

Bruno, V., \& Shin, H. S. (2015a). Capital flows and the risk-taking channel of monetary policy. Journal of Monetary Economics, 71, 119-132.

Bruno, V., \& Shin, H. S. (2015b). Cross-border banking and global liquidity. The Review of Economic Studies, 82(2), 535-564.

Bruno, V., \& Shin, H. S. (2017). Global dollar credit and carry trades: a firm-level analysis. The Review of Financial Studies, 30(3), 703-749.

Caballero, J., Panizza, U., \& Powell, A. (2016). The second wave of global liquidity: Why are firms acting like financial intermediaries? (No. w641). Inter-American Development Bank Working Papers

Caglio, C. R., Darst, R. M., \& Kalemli-Özcan, Ș. (2021). Risk-Taking and Monetary Policy Transmission: Evidence from Loans to SMEs and Large Firms (No. w28685). National Bureau of Economic Research.

Cameron, A. C., \& Miller, D. L. (2015). A practitioner's guide to cluster-robust inference. Journal of Human Resources, 50(2), 317-372.

Cavallino, P., \& Sandri, D. (2019). The expansionary lower bound: Contractionary monetary easing and the trilemma (No. w770). BIS Working Papers.

Cerutti, E. M., Obstfeld, M., \& Zhou, H. (2019). Covered interest parity deviations: Macrofinancial determinants (No. w26129). National Bureau of Economic Research.

Cetorelli, N., \& Goldberg, L. S. (2012). Banking globalization and monetary transmission. The Journal of Finance, 67(5), 1811-1843.

Claessens, S. (2015). An overview of macroprudential policy tools. Annual Review of Financial Economics, 7(1), 397-422.

Cordella, T., Federico, P., Vegh, C., \& Vuletin, G. (2014). Reserve requirements in the brave new macroprudential world. The World Bank.

Dagher, J., \& Kazimov, K. (2015). Banks' liability structure and mortgage lending during the financial crisis. Journal of Financial Economics, 116(3), 565-582. 
Davis, J. S., \& Presno, I. (2017). Capital controls and monetary policy autonomy in a small open economy. Journal of Monetary Economics, 85, 114-130.

Demirgüç-Kunt, A., \& Huizinga, H. (2010). Bank activity and funding strategies: The impact on risk and returns. Journal of Financial Economics, 98(3), 626-650.

Dias, D., Huang, Y., Rey, H., \& Sarmiento, M. (2021). Monetary policy with and without capital controls: Micro evidence from Colombia. Mimeo.

Du, W., \& Schreger, J. (2016). Local currency sovereign risk. The Journal of Finance, 71(3), 1027-1070.

Du, W., Tepper, A., \& Verdelhan, A. (2018). Deviations from covered interest rate parity. The Journal of Finance, 73(3), 915-957.

Erten, B., Korinek, A., \& Ocampo, J. A. (2019). Capital controls: Theory and evidence (No. w26447). National Bureau of Economic Research.

Fabiani, A., López, M., Peydró, J. L., \& Soto, P.E. (2021). Capital controls, corporate debt and real effects. Mimeo.

Farhi, E., \& Werning, I. (2012). Dealing with the trilemma: Optimal capital controls with fixed exchange rates (No. w18199). National Bureau of Economic Research.

Farhi, E., \& Werning, I. (2014). Dilemma not trilemma? Capital controls and exchange rates with volatile capital flows. IMF Economic Review, 62(4), 569-605.

Farhi, E., \& Werning, I. (2016). A theory of macroprudential policies in the presence of nominal rigidities. Econometrica, 84(5), 1645-1704.

Federico, P., Vegh, C. A., \& Vuletin, G. (2014). Reserve requirement policy over the business cycle (No. w20612). National Bureau of Economic Research.

Fendoglu, S., Gulsen, E., \& Peydro, J. L. (2019). Global liquidity and the impairment of local monetary policy transmission (No. 1913). Central Bank of Turkey Working Papers.

Forbes, K. J., \& Warnock, F. E. (2012). Capital flow waves: Surges, stops, flight, and retrenchment. Journal of International Economics, 88(2), 235-251.

Freixas, X., Laeven, L., \& Peydró, J. L. (2015). Systemic risk, crises, and macroprudential regulation. Mit Press.

Galati, G., \& Moessner, R. (2013). Macroprudential policy-a literature review. Journal of Economic Surveys, 27(5), 846-878.

Galati, G., \& Moessner, R. (2018). What do we know about the effects of macroprudential policy?. Economica, 85(340), 735-770. 
Gourinchas, P. O., \& Obstfeld, M. (2012). Stories of the twentieth century for the twenty-first. American Economic Journal: Macroeconomics, 4(1), 226-65.

Hahm, J. H., Shin, H. S., \& Shin, K. (2013). Non-core bank liabilities and financial vulnerability. Journal of Money, Credit and Banking, 45, 3-36.

Han, X., \& Wei, S. J. (2018). International transmissions of monetary shocks: Between a trilemma and a dilemma. Journal of International Economics, 110, 205-219.

IMF (International Monetary Fund). (2012). The liberalization and management of capital flows - An institutional view. Policy Paper, Washington, DC.

IMF (International Monetary Fund). (2018). The IMF's institutional view on capital flows in practice. Policy Paper, Washington, DC.

IMF (International Monetary Fund). (2019). Chapter 5 Banks' Dollar Funding. In Global Financial Stability Report, October 2019 : Lower for Longer, Washington, DC.

Ivashina, V., Scharfstein, D. S., \& Stein, J. C. (2015). Dollar funding and the lending behavior of global banks. The Quarterly Journal of Economics, 130(3), 1241-1281.

Jeanne, O., \& Korinek, A. (2010). Excessive volatility in capital flows: A pigouvian taxation approach. American Economic Review, 100(2), 403-07.

Jiménez, G., Mian, A., Peydró, J. L., \& Saurina, J. (2019). The real effects of the bank lending channel. Journal of Monetary Economics.

Jiménez, G., Ongena, S., Peydró, J. L., \& Saurina, J. (2012). Credit supply and monetary policy: Identifying the bank balance-sheet channel with loan applications. American Economic Review, 102(5), 2301-26.

Jiménez, G., Ongena, S., Peydró, J. L., \& Saurina, J. (2014). Hazardous times for monetary policy: What do twenty three million bank loans say about the effects of monetary policy on credit risk taking?. Econometrica, 82(2), 463-505.

Jiménez, G., Ongena, S., Peydró, J. L., \& Saurina, J. (2017). Macroprudential policy, countercyclical bank capital buffers, and credit supply: evidence from the Spanish dynamic provisioning experiments. Journal of Political Economy, 125(6), 2126-2177.

Jordà, Ò. (2005). Estimation and inference of impulse responses by local projections. American economic review, 95(1), 161-182.

Jordà, Ò., Schularick, M., \& Taylor, A. M. (2011). Financial crises, credit booms, and external imbalances: 140 years of lessons. IMF Economic Review, 59(2), 340-378.

Julio, J. M., Lozano, I., \& Melo, L. A. (2013). Global risk appetite and EMBI-Colombia: evidence on a structural break and the fiscal policy role.Ensayos Sobre Politica Económica, 31(72), 67-73. 
Kashyap, A. K., \& Stein, J. C. (2000). What do a million observations on banks say about the transmission of monetary policy?. American Economic Review, 90(3), 407-428.

Khwaja, A. I., \& Mian, A. (2008). Tracing the impact of bank liquidity shocks: Evidence from an emerging market. American Economic Review, 98(4), 1413-42.

Klein, M. W., \& Shambaugh, J. C. (2015). Rounding the corners of the policy trilemma: sources of monetary policy autonomy. American Economic Journal: Macroeconomics, 7(4), 33-66.

Koijen, R. S., Moskowitz, T. J., Pedersen, L. H., \& Vrugt, E. B. (2018). Carry. Journal of Financial Economics, 127(2), 197-225.

Korinek, A. (2011). The new economics of prudential capital controls: A research agenda. IMF Economic Review, 59(3), 523-561.

Korinek, A. (2018). Regulating capital flows to emerging markets: An externality view. Journal of International Economics, 111, 61-80.

Korinek, A., \& Sandri, D. (2016). Capital controls or macroprudential regulation?. Journal of International Economics, 99, S27-S42.

Liao, G.Y. (2020). Credit migration and covered interest rate parity. Journal of Financial Economics, 138(2), pp.504-525.

López, M., Tenjo, F., \& Zárate, H. (2014). Credit cycles, credit risk and countercyclical loan provisions. Ensayos sobre Política Económica, 32(74), 9-17.

Mendoza, E. G., \& Terrones, M. E. (2008). An anatomy of credit booms: evidence from macro aggregates and micro data (No. w14049). National Bureau of Economic Research.

Miranda-Agrippino, S., \& Rey, H. (2020). US monetary policy and the global financial cycle. The Review of Economic Studies, 87(6), 2754-2776.

Morais, B., Ormazabal, G., Peydró, J. L., Roa, M., \& Sarmiento, M. (2020). Forward Looking Loan Provisions: Credit Supply and Risk-Taking (No. w1199). Barcelona GSE Working Paper Series.

Morais, B., Peydró, J. L., Roldán Peña, J., \& Ruiz Ortega, C. (2019). The international bank lending channel of monetary policy rates and QE: Credit supply, reach for yield, and real effects. The Journal of Finance, 74(1), 55-90.

Ongena, S., Schindele, I., \& Vonnák, D. (2021). In lands of foreign currency credit, bank lending channels run through?. Journal of International Economics, 129, 103435.

Österholm, P., \& Zettelmeyer, J. (2008). The effect of external conditions on growth in Latin America. IMF Staff Papers, 55(4), 595-623. 
Ostry, J.D., Ghosh, A.R., Habermeier, K., Chamon, M., Qureshi, M.S. and Reinhardt, D.B.S. (2010). Capital inflows: the role of controls. IMF Staff Position Note SPN/10/04. International Monetary Fund.

Qureshi, M. S., Ostry, J. D., Ghosh, A. R., \& Chamon, M. (2011). Managing capital inflows: The role of capital controls and prudential policies (No. w17363). National Bureau of Economic Research.

Rebucci, A., \& Ma, C. (2019). Capital controls: A survey of the new literature (No. w26558). National Bureau of Economic Research.

Reinhart, C. M., \& Reinhart, V. R. (2008). Capital flow bonanzas: an encompassing view of the past and present (No. w14321). National Bureau of Economic Research.

Rey, H. (2015). Dilemma not trilemma: the global financial cycle and monetary policy independence (No. w21162). National Bureau of Economic Research.

Schmitt-Grohé, S., \& Uribe, M. (2016). Downward nominal wage rigidity, currency pegs, and involuntary unemployment. Journal of Political Economy, 124(5), 1466-1514.

Schularick, M., \& Taylor, A. M. (2012). Credit booms gone bust: Monetary policy, leverage cycles, and financial crises, 1870-2008. American Economic Review, 102(2), 1029-61.

Zeev, N. B. (2017). Capital controls as shock absorbers. Journal of International Economics, 109, 43-67. 